Supplement of Geosci. Model Dev., 13, 5311-5343, 2020

https://doi.org/10.5194/gmd-13-5311-2020-supplement

(C) Author(s) 2020. This work is distributed under

the Creative Commons Attribution 4.0 License.

(c) (1)

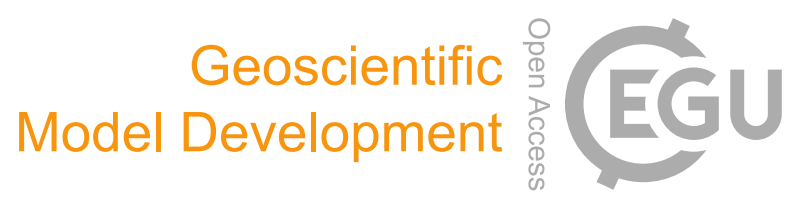

Supplement of

\title{
Description and evaluation of the process-based forest model 4C v2.2 at four European forest sites
}

Petra Lasch-Born et al.

Correspondence to: Petra Lasch-Born (lasch@pik-potsdam.de), and Felicitas Suckow (suckow@ pik-potsdam.de)

The copyright of individual parts of the supplement might differ from the CC BY 4.0 License. 


\section{Contents}

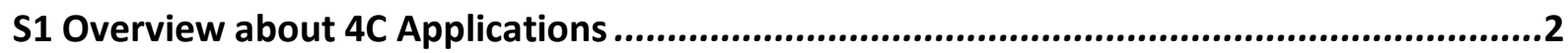

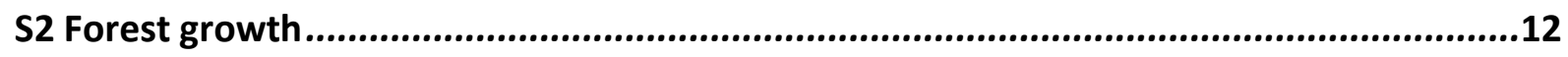

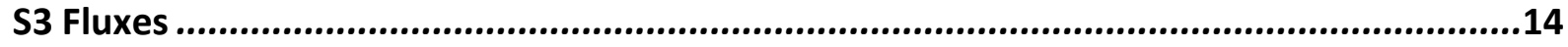

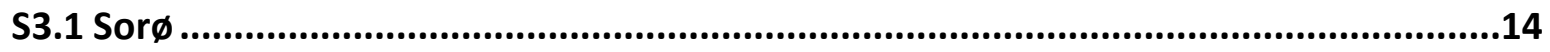

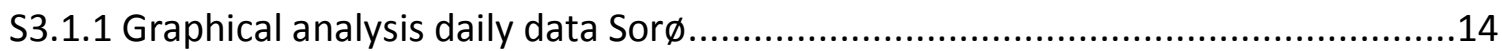

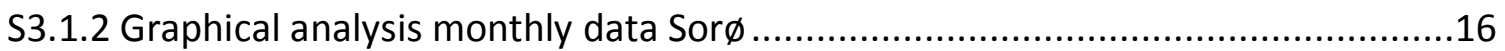

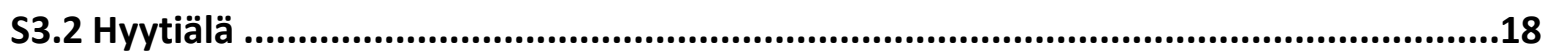

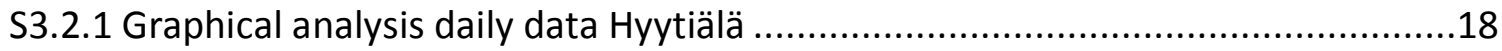

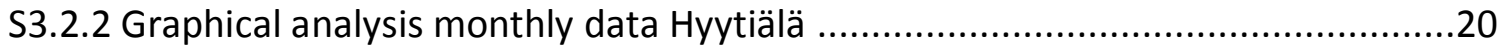

S3.2.3 Graphical analysis of soil temperature and water content Hyytiälä ...................22

S3.3 Analysis of deviations of actual evapotranspiration ..............................................23

S4 Soil temperature and water content Hyytiälä.........................................................24

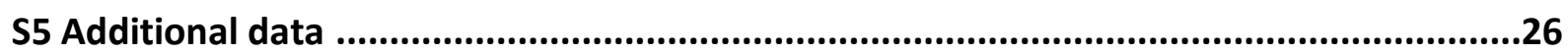

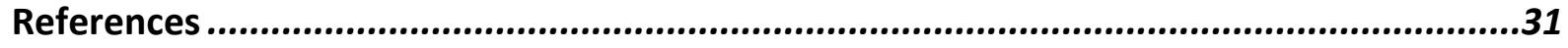




\section{S1 OVERVIEW ABOUT 4C APPLICATIONS}

Table S1 Applications of the model 4C

\begin{tabular}{|c|c|c|c|}
\hline Publication & Region & Analysis & Results \\
\hline Lasch et al., 2002 & $\begin{array}{l}\text { Pine stand in Brandenburg, several } 24 \\
\text { pine, spruce, oak and beech stands in } \\
\text { Germany }\end{array}$ & $\begin{array}{l}\text { Sensitivity study regarding climate and } \\
\text { growth analysis under climate change }\end{array}$ & $\begin{array}{l}\text { Water limitation effects for forest growth } \\
\text { in German temperate forests are } \\
\text { important and an increasing direct effect } \\
\text { of rising temperatures at higher elevation } \\
\text { sites is shown. }\end{array}$ \\
\hline Gerstengarbe et al., 2003 & Brandenburg/ Germany & $\begin{array}{l}\text { Effects of climate change on carbon } \\
\text { budget and water balance of forests in } \\
\text { Brandenburg using } 461 \text { forest stands and } \\
\text { one climate scenario }\end{array}$ & $\begin{array}{l}\text { The effects of climate change were } \\
\text { stronger for the water balance than for the } \\
\text { carbon budget due to the assumed climate } \\
\text { scenario. }\end{array}$ \\
\hline Badeck et al., 2005 & $\begin{array}{l}\text { Management unit in Brandenburg/ } \\
\text { Germany }\end{array}$ & $\begin{array}{l}\text { Application of adaptive forest } \\
\text { management strategies and climate } \\
\text { scenarios to a management unit in } \\
\text { Brandenburg }\end{array}$ & 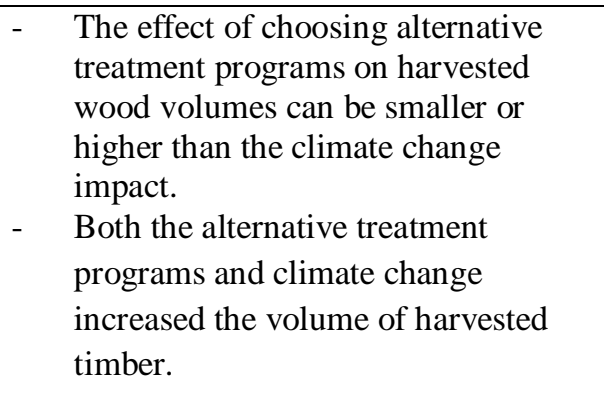 \\
\hline Fürstenau et al., 2007 & $\begin{array}{l}\text { Management unit in Brandenburg/ } \\
\text { Germany }\end{array}$ & $\begin{array}{l}\text { Evaluation of alternative management } \\
\text { strategies at the forest management unit } \\
\text { level under current climate and under } \\
\text { transient climate change conditions over a } \\
\text { planning period of } 100 \text { years. Application }\end{array}$ & 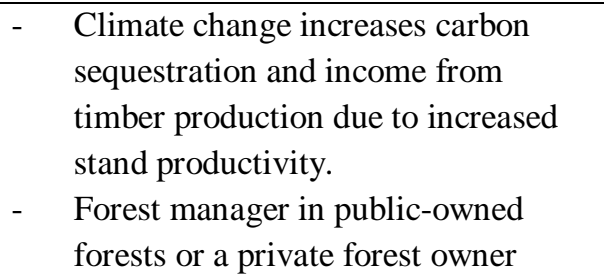 \\
\hline
\end{tabular}




\begin{tabular}{|c|c|c|c|}
\hline Publication & Region & Analysis & Results \\
\hline & & of a multi-criteria analysis method & $\begin{array}{l}\text { would prefer a management strategy } \\
\text { with an intermediate thinning } \\
\text { intensity and a high share of pine } \\
\text { stands }\end{array}$ \\
\hline Lasch et al., 2007 & $\begin{array}{l}3 \text { Level II ICP Forest plots in } \\
\text { Brandenburg, Lower Saxony and Bavaria }\end{array}$ & $\begin{array}{l}\text { Application of climate scenarios with } \\
\text { temperature increase and varying } \\
\text { precipitation changes to analyse carbon } \\
\text { budget of the forest stands. }\end{array}$ & $\begin{array}{l}\text { Model simulated an increase in carbon } \\
\text { stock of stem biomass, deadwood and } \\
\text { soil. }\end{array}$ \\
\hline Meiwes et al., 2007 & $\begin{array}{l}21 \text { Level II plots in Bavaria, Brandenburg } \\
\text { and Lower Saxony Germany }\end{array}$ & Modeling of the carbon budgets & $\begin{array}{l}\text { Models are suitable instruments for the } \\
\text { analysis of the observation data from the } \\
\text { monitoring plots. The combination of } \\
\text { monitoring and modelling allows the } \\
\text { evaluation of effects of climate change } \\
\text { and forest management. }\end{array}$ \\
\hline Seidl et al., 2008 & $\begin{array}{l}\text { Forest management unit in Carinthia, } \\
\text { southern Austria }\end{array}$ & $\begin{array}{l}\text { Application of different management } \\
\text { strategies under current climate and } \\
\text { transient climate change and comparison } \\
\text { with the model PICUS }\end{array}$ & $\begin{array}{l}\text { - A transition to continuous cover } \\
\text { forestry increased C storage in all } \\
\text { climate scenarios compared to the } \\
\text { approximately balanced C budget } \\
\text { under the age class system. } \\
\text { - With regard to climate change } \\
\text { impacts both models agreed on } \\
\text { distinct effects on productivity but } \\
\text { lower sensitivity of C stocks due to } \\
\text { compensation from respiration and } \\
\text { adaptive harvest levels }\end{array}$ \\
\hline Wechsung et al., 2009 & $\begin{array}{l}\text { Agricultural land in the } 5 \text { Federal states of } \\
\text { East Germany }\end{array}$ & $\begin{array}{l}\text { Model based yield estimation of aspen } \\
\text { short rotation coppice SRC under climate }\end{array}$ & $\begin{array}{l}\text { Yields of fast growing aspen in SRC are } \\
\text { expected to increase under the presumed } \\
\text { changes of climate also on sandy soils }\end{array}$ \\
\hline
\end{tabular}




\begin{tabular}{|c|c|c|c|}
\hline Publication & Region & Analysis & Results \\
\hline & & change & $\begin{array}{l}\text { with low water holding capacity even } \\
\text { when neglecting the beneficial effect of } \\
\text { higher } \mathrm{CO}_{2} \text {. }\end{array}$ \\
\hline Kint et al., 2009 & Galgenberg forest in the Netherlands & $\begin{array}{l}\text { Investigation how conversion } \\
\text { management of a Scots pine Pinus } \\
\text { sylvestris L. stand towards a mixed oak- } \\
\text { birch stand would affect stand structural } \\
\text { development and hence biodiversity and } \\
\text { productivity in the long term. }\end{array}$ & $\begin{array}{l}\text { The optimal conversion regime - in } \\
\text { which both stand productivity and } \\
\text { biodiversity objectives can be combined - } \\
\text { implies thinning from above, pine tree } \\
\text { retention, and cutting cycles of } 6 \text { years. }\end{array}$ \\
\hline Kollas et al., 2009 & Agricultural land in Germany & $\begin{array}{l}\text { Exploration the actual and future energy } \\
\text { potential of short-rotation cop scenarios. }\end{array}$ & $\begin{array}{l}\text { - } \quad \text { If } 4 \text { m ha were used as SRC, between } \\
415 \text { and } 522 \text { PJ a- } 1 \text { of primary energy } \\
\text { could be produced in the scenario } \\
\text { periods 2041-2060. } \\
\text { - } \quad \text { SRC can deliver a substantial } \\
\text { contribution to the primary energy } \\
\text { production in } 2060 .\end{array}$ \\
\hline Lasch et al., 2009 & $\begin{array}{l}\text { Mixed Scots pine-oak stands in } \\
\text { Brandenburg Germany }\end{array}$ & $\begin{array}{l}\text { Analysis of carbon and water budget with } \\
\text { various management strategies and under } \\
\text { climate change; comparison with the } \\
\text { model BWINPro }\end{array}$ & $\begin{array}{l}\text { 4C allows the analysis of various } \\
\text { ecosystem functions and the evaluation of } \\
\text { management strategies regarding these } \\
\text { functions. }\end{array}$ \\
\hline Lasch et al., 2010 & $\begin{array}{l}\text { Agricultural land in the } 5 \text { Federal states of } \\
\text { East Germany }\end{array}$ & $\begin{array}{l}\text { Estimation of the potential woody } \\
\text { biomass yield of SRC plantations with } \\
\text { aspen on suitable land in Eastern } \\
\text { Germany under climate change and } \\
\text { evaluation how aspen SRC plantation } \\
\text { affects groundwater recharge and the } \\
\text { impacts of land use change on the soil }\end{array}$ & $\begin{array}{l}\text { Aspen SRC plantations are a suitable } \\
\text { contribution to regional } \mathrm{CO}_{2} \text { mitigation } \\
\text { and carbon sequestration under possible } \\
\text { change of climate, but that negative } \\
\text { impacts on the regional water budget are } \\
\text { possible. }\end{array}$ \\
\hline
\end{tabular}




\begin{tabular}{|c|c|c|c|}
\hline Publication & Region & Analysis & Results \\
\hline & & properties. & \\
\hline Reyer et al., 2010 & $\begin{array}{l}\text { Mixed Douglas fir- beech stands in } \\
\text { Germany and in the Netherlands }\end{array}$ & $\begin{array}{l}\text { Climate change effects on the inter- } \\
\text { specific competition in a managed } \\
\text { Douglas-fir/beech mixed forest. }\end{array}$ & $\begin{array}{l}\text { Simulated climate change does not } \\
\text { substantially alter the interaction of the } \\
\text { two species. The concept of } \\
\text { complementary water use highlights the } \\
\text { importance of mixed forest for climate } \\
\text { change adaptation. }\end{array}$ \\
\hline Gutsch et al., 2011 & $\begin{array}{l}\text { Mixed oak-pine stand in Brandenburg/ } \\
\text { Germany }\end{array}$ & $\begin{array}{l}\text { Analysis of different management } \\
\text { scenarios under climate change }\end{array}$ & 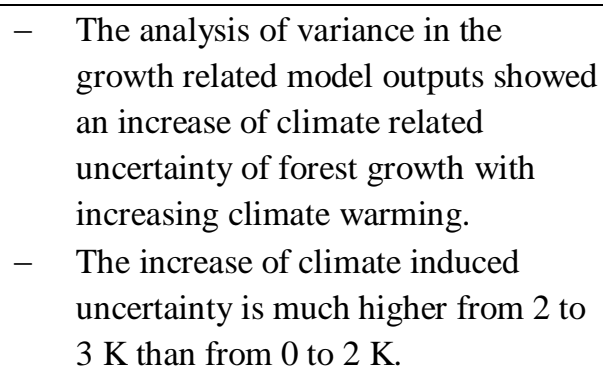 \\
\hline Borys et al., 2013 & $\begin{array}{l}\text { Four beech forests of a management unit } \\
\text { in Thuringia }\end{array}$ & $\begin{array}{l}\text { Analysis of carbon budget of the long- } \\
\text { term experimental stands using a wood } \\
\text { product model }\end{array}$ & 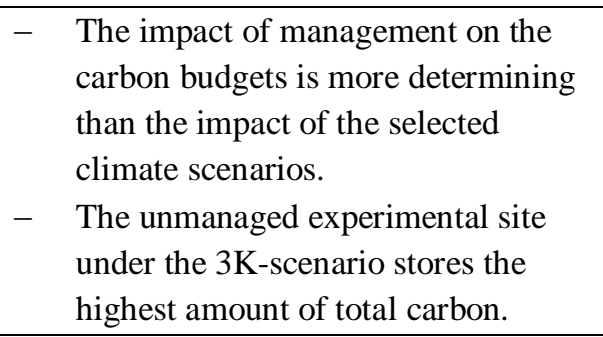 \\
\hline van Oijen et al., 2013 & $\begin{array}{l}\text { Twelve sites, from Austria, Belgium, } \\
\text { Estonia and Finland. }\end{array}$ & $\begin{array}{l}\text { Evaluation how Bayesian calibration BC, } \\
\text { Bayesian model comparison BMC and } \\
\text { Bayesian model averaging BMA can help } \\
\text { to assess the uncertainty of model } \\
\text { predictions. }\end{array}$ & $\begin{array}{l}\text { - } \quad \text { BC reduced uncertainties strongly in } \\
\text { all but the most complex model. } \\
\text { - } \quad \text { BMC using NFI- and PSP-data } \\
\text { identified the 4C model, which is of } \\
\text { moderate complexity but }\end{array}$ \\
\hline
\end{tabular}




\begin{tabular}{|c|c|c|c|}
\hline Publication & Region & Analysis & Results \\
\hline & & & $\begin{array}{l}\text { mechanistic, as the most plausible } \\
\text { forest model after calibration. }\end{array}$ \\
\hline Stojanović et al., 2014 & $\begin{array}{l}\text { Nine European beech forest sites in } \\
\text { Serbia }\end{array}$ & $\begin{array}{l}\text { Integration of stakeholder preferences, } \\
\text { experts’ opinion and forest growth } \\
\text { modelling for climate and management } \\
\text { scenario assessments }\end{array}$ & $\begin{array}{l}\text { - Forest management together with } \\
\text { stakeholder preferences will play } \\
\text { much bigger role in providing of } \\
\text { better support for ecosystem service } \\
\text { in comparison to climate conditions } \\
\text { - } \\
\text { frequent felling operations provide } \\
\text { better result than less frequent } \\
\text { operations for the same amount of } \\
\text { harvested wood. }\end{array}$ \\
\hline Reyer et al., 2014 & $\begin{array}{l}132 \text { typical forest sites of important } \\
\text { European tree species in ten } \\
\text { environmental zones in Europe. }\end{array}$ & $\begin{array}{l}\text { Projection of forest productivity changes } \\
\text { under different climate change scenarios } \\
\text { at a large number of sites in Europe with } \\
\text { a stand-scale process-based model. }\end{array}$ & $\begin{array}{l}\text { - Future forest productivity will be } \\
\text { affected by climate change and these } \\
\text { effects depend strongly on the } \\
\text { climate scenario used and the } \\
\text { persistence of } \mathrm{CO}_{2} \text { effects. } \\
\text { Productivity increases in Northern } \\
\text { Europe, increases or decreases in } \\
\text { Central Europe, and decreases in } \\
\text { Southern Europe. }\end{array}$ \\
\hline Borys et al., 2015 & Management unit in Thuringia Buchfahrt & $\begin{array}{l}\text { Economic analysis of the beech stands of } \\
\text { the considered management unit }\end{array}$ & 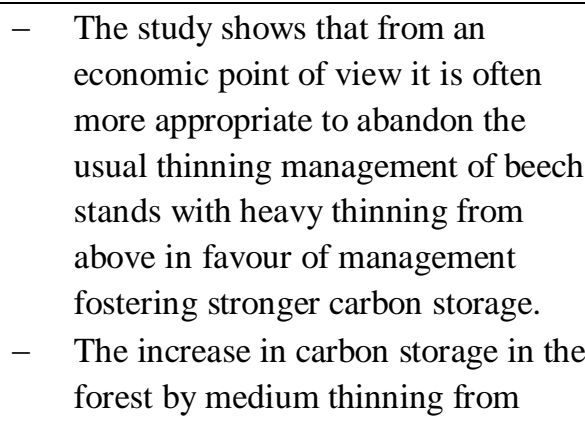 \\
\hline
\end{tabular}




\begin{tabular}{|c|c|c|c|}
\hline Publication & Region & Analysis & Results \\
\hline & & & $\begin{array}{l}\text { below and no management was, } \\
\text { however, associated with additional } \\
\text { costs or lower revenues of } 112 € \text { and } \\
123 € \text { per additional ton of carbon } \\
\text { stored respectively. }\end{array}$ \\
\hline Gutsch et al., 2015a & Agriculture and Forestry in Germany & $\begin{array}{l}\text { Assessment of the uncertainty caused by } \\
\text { climate change effects in the potential } \\
\text { supply of biomass available for energy } \\
\text { production. }\end{array}$ & $\begin{array}{l}\text { In five federal states the climate scenarios } \\
\text { lead to decreasing yields of energy maize } \\
\text { and winter wheat. Impacts of climate } \\
\text { scenarios on forest yields are mainly } \\
\text { positive and show both positive and } \\
\text { negative effects on yields of SRC. }\end{array}$ \\
\hline Gutsch et al., 2015b & $\begin{array}{l}\text { Two mono-species Scots pine stands and } \\
\text { two mixed Scots pine-oak stands in the } \\
\text { lowlands of northeastern Germany. }\end{array}$ & $\begin{array}{l}\text { Analysis of two water uptake approaches } \\
\text { an empirical and a more process-based } \\
\text { one in Scots pine and Scots pine-Sessile } \\
\text { oak stands. }\end{array}$ & $\begin{array}{l}\text { Accurate projections of future forest } \\
\text { productivity depend largely on the } \\
\text { realistic representation of root water } \\
\text { uptake in forest model simulations. Three } \\
\text { different measured parameters } \\
\text { transpiration, soil water content, tree rings } \\
\text { did not allow a superior approach to each } \\
\text { other. }\end{array}$ \\
\hline Schelhaas et al., 2015 & Europe & $\begin{array}{l}\text { The data from Reyer et al. } 2014 \text { was used } \\
\text { to scale the future productivity changes in } \\
\text { EFISCEN. }\end{array}$ & $\begin{array}{l}\text { The European forest system is very inert } \\
\text { and it takes a long time to influence the } \\
\text { species distribution by replacing species } \\
\text { after final felling. By 2070, on average } \\
\text { about } 36 \% \text { of the area expected to have } \\
\text { decreased species suitability will have } \\
\text { changed species following business as } \\
\text { usual management. Alternative } \\
\text { management, consisting of shorter } \\
\text { rotations for those species and species }\end{array}$ \\
\hline
\end{tabular}




\begin{tabular}{|c|c|c|c|}
\hline Publication & Region & Analysis & Results \\
\hline & & & $\begin{array}{l}\text { planting based on expected trends, will } \\
\text { have increased this species transition to } \\
40 \% \text {. }\end{array}$ \\
\hline Lasch-Born et al., 2015 & Forested area in Germany & $\begin{array}{l}\text { How do changes in net primary } \\
\text { production and timber production interact } \\
\text { with changes in the water budget under } \\
\text { climate change? What are the possible } \\
\text { risks of fire danger or pest outbreaks? }\end{array}$ & $\begin{array}{l}\text { The dryer water-limited low elevated } \\
\text { regions reaching from southwestern to } \\
\text { northeastern Germany will benefit less } \\
\text { from the assumed climate change than } \\
\text { regions in the Northwest and forest sites } \\
\text { at higher altitudes, which are mainly } \\
\text { temperature limited. }\end{array}$ \\
\hline Borys et al., 2016 & $\begin{array}{l}\text { Forest management unit in Thuringia } \\
\text { Buchfahrt }\end{array}$ & $\begin{array}{l}\text { Assessment how much carbon } \mathrm{C} \text { is } \\
\text { currently stored in a forest district and } \\
\text { how the carbon stocks will develop up to } \\
\text { the year } 2099 \text { with a changing climate } \\
\text { and under various management regimes } \\
\text { including no management, with different } \\
\text { assumptions about carbon dioxide } \mathrm{CO}_{2} \\
\text { fertilization effects. }\end{array}$ & $\begin{array}{l}\text { Climate change affects carbon } \\
\text { sequestration. The no management } \\
\text { strategy sequestered the highest amount } \\
\text { of carbon which was greater than the } \\
\text { management regimes. In the model, the } \\
\text { possible fertilization effect of } \mathrm{CO}_{2} \text { is an } \\
\text { important factor. However, forest } \\
\text { management remains the determining } \\
\text { factor in this forest district. }\end{array}$ \\
\hline Gutsch et al., 2016 & Forest area Germany & $\begin{array}{l}\text { This study aims to derive simple models } \\
\text { from } 4 \mathrm{C} \text { simulations with low data } \\
\text { requirements which allow calculation of } \\
\text { NPP and analysis of climate impacts } \\
\text { using many climate scenarios at a large } \\
\text { amount of sites. }\end{array}$ & $\begin{array}{l}\text { The fitted regression functions showed a } \\
\text { reasonable fit to measured NPP datasets. } \\
\text { Temperature increase of up to } 3 \mathrm{~K} \text { leads } \\
\text { to positive effects on NPP. In water- } \\
\text { limited regions, this positive effect is } \\
\text { dependent on the length of drought } \\
\text { periods. }\end{array}$ \\
\hline Reyer et al., 2016 & Two NFI sites each from Austria, & This paper aims to integrate parameter & If a key objective in climate change \\
\hline
\end{tabular}




\begin{tabular}{|c|c|c|c|}
\hline Publication & Region & Analysis & Results \\
\hline & Belgium, Estonia and Finland & $\begin{array}{l}\text { uncertainty into simulations of climate } \\
\text { change impacts on forest net primary } \\
\text { productivity NPP. Application of either } \\
\text { prior uncalibrated or posterior calibrated } \\
\text { using Bayesian calibration parameter } \\
\text { variations to express parameter } \\
\text { uncertainty. }\end{array}$ & $\begin{array}{l}\text { impact research is to quantify uncertainty, } \\
\text { parameter uncertainty as a major factor } \\
\text { driving the degree of uncertainty of } \\
\text { projections should be included. }\end{array}$ \\
\hline Suckow et al., 2016 & Scots pine stand Zotino Siberia, Russia & $\begin{array}{l}\text { Analysis of impacts of climate change on } \\
\text { a pine forest stand in Central Siberia to } \\
\text { assess benefits and risks for such forests } \\
\text { in the future. }\end{array}$ & $\begin{array}{l}\text { The analysis confirms increasing } \\
\text { productivity of the boreal pine stand but } \\
\text { also highlights increasing drought stress } \\
\text { and risks from abiotic disturbances which } \\
\text { could cancel out productivity gains. }\end{array}$ \\
\hline Horemans et al., 2017 & $\begin{array}{l}\text { FLUXNET sites: Soroe Denmark, } \\
\text { Vielsalm Belgium and Collelongo Italy. }\end{array}$ & $\begin{array}{l}\text { The performance of two global dynamic } \\
\text { vegetation models, i.e. CARAIB and } \\
\text { ISBACC, and one stand-scale forest } \\
\text { model, i.e. 4C, was compared to long- } \\
\text { term observed net ecosystem carbon } \\
\text { exchange NEE time series from eddy } \\
\text { covariance monitoring stations at three } \\
\text { old-grown European beech Fagus } \\
\text { sylvatica L. forest stands }\end{array}$ & 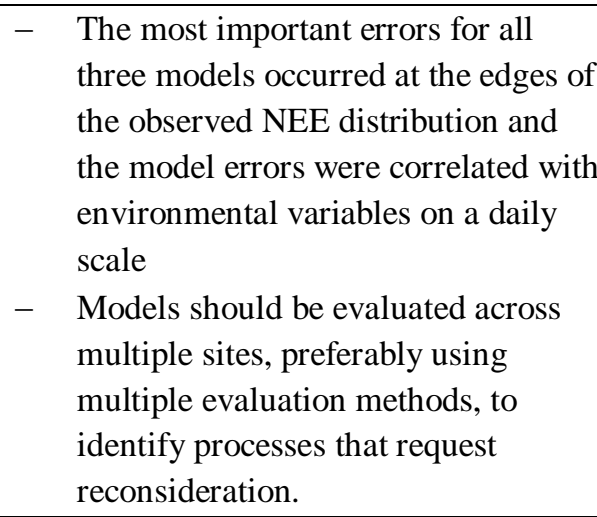 \\
\hline Gutsch et al., 2018 & Germany’s forests, NFI data BWI ${ }^{3}$ & $\begin{array}{l}\text { Quantification o the effects of two } \\
\text { alternative management scenarios and } \\
\text { climate impacts on forest variables } \\
\text { indicative of ecosystem services related to }\end{array}$ & $\begin{array}{l}\text { - } \\
\text { Northeastern and western forest } \\
\text { regions are more suitable to provide } \\
\text { timber while minimizing the negative } \\
\text { impacts on remaining ecosystem } \\
\text { services whereas southern and central }\end{array}$ \\
\hline
\end{tabular}




\begin{tabular}{|c|c|c|c|}
\hline Publication & Region & Analysis & Results \\
\hline & & timber, habitat, water, and carbon. & $\begin{array}{l}\text { forest regions are more suitable to } \\
\text { fulfil 'habitat' and 'carbon' services. } \\
\text { _ } \quad \text { The results provide the base for } \\
\text { future forest management } \\
\text { optimizations at the regional scale in } \\
\text { order to maximize ecosystem } \\
\text { services and forest ecosystem } \\
\text { sustainability at the national scale. }\end{array}$ \\
\hline Kollas et al., 2018 & Scots pine stand in Berlin Germany & $\begin{array}{l}\text { Estimation of mistletoe-induced losses in } \\
\text { timber yield applying the process-based } \\
\text { forest growth model 4C. }\end{array}$ & $\begin{array}{l}\text { Simulations showed that the amended } \\
\text { forest growth model } 4 \mathrm{C} \text { depicts well the } \\
\text { BAI growth pattern during }>100 \text { years } \\
\text { and also quantifies well the mistletoe- } \\
\text { induced growth reductions in Scots pine } \\
\text { stands. }\end{array}$ \\
\hline Yousefpour et al., 2018 & Forest stands in 18 European countries & $\begin{array}{l}\text { Simulation of European commercial } \\
\text { forests' growth conditions and coupled it } \\
\text { with an optimization algorithm to } \\
\text { simulate the implementation of Climate } \\
\text { Smart Forestry for } 18 \text { European countries } \\
\text { encompassing } 68.3 \text { million ha of forest } \\
42.4 \% \text { of total EU-28 forest area }\end{array}$ & $\begin{array}{l}\text { A European Climate Smart Forestry CSF } \\
\text { policy could sequester } 7.3-11.1 \text { billion } \\
\text { tons of carbon, projected to be worth } 103 \\
\text { to } 141 \text { billion euros in the } 21 \text { st century. } \\
\text { An efficient CSF policy would allocate } \\
\text { carbon sequestration to European } \\
\text { countries with a lower wood price, lower } \\
\text { labour costs, high harvest costs, or a } \\
\text { mixture thereof to increase its economic } \\
\text { efficiency. }\end{array}$ \\
\hline Lasch-Born et al., 2018 & Germany’s forests & $\begin{array}{l}\text { Ongoing climate change affects growth } \\
\text { and increases biotic and abiotic threats to } \\
\text { Germany’s forests. How do these risks } \\
\text { develop through the mid-century under a }\end{array}$ & $\begin{array}{l}\text { All indicators showed higher risks for the } \\
\text { scenario time period compared to the } \\
\text { recent time period, except the late frost } \\
\text { risk indicators, if averaged over all }\end{array}$ \\
\hline
\end{tabular}




\begin{tabular}{|c|c|c|c|}
\hline Publication & Region & Analysis & Results \\
\hline & & $\begin{array}{l}\text { variety of climate change scenarios using } \\
4 \mathrm{C} \text { ? }\end{array}$ & $\begin{array}{l}\text { climate scenarios. The late frost risk for } \\
\text { beech and oaks decreased for the main } \\
\text { forest sites. }\end{array}$ \\
\hline Bugmann et al., 2019 & Scots pine stand Peitz Germany 4C & $\begin{array}{l}\text { Evaluation } 15 \text { dynamic vegetation models } \\
\text { DVMs regarding their sensitivity to } \\
\text { different formulations of tree mortality } \\
\text { under different degrees of climate change. }\end{array}$ & $\begin{array}{l}1 \text { Mortality is one of the most uncertain } \\
\text { processes when it comes to assessing } \\
\text { forest response to climate change, and } 2 \\
\text { more data and a better process } \\
\text { understanding of tree mortality are } \\
\text { needed to improve the robustness of } \\
\text { simulated future forest dynamics. Our } \\
\text { study highlights that comparing several } \\
\text { alternative mortality formulations in } \\
\text { DVMs provides valuable insights into the } \\
\text { effects of process uncertainties on } \\
\text { simulated future forest dynamics. }\end{array}$ \\
\hline
\end{tabular}




\section{S2 FOREST GROWTH}
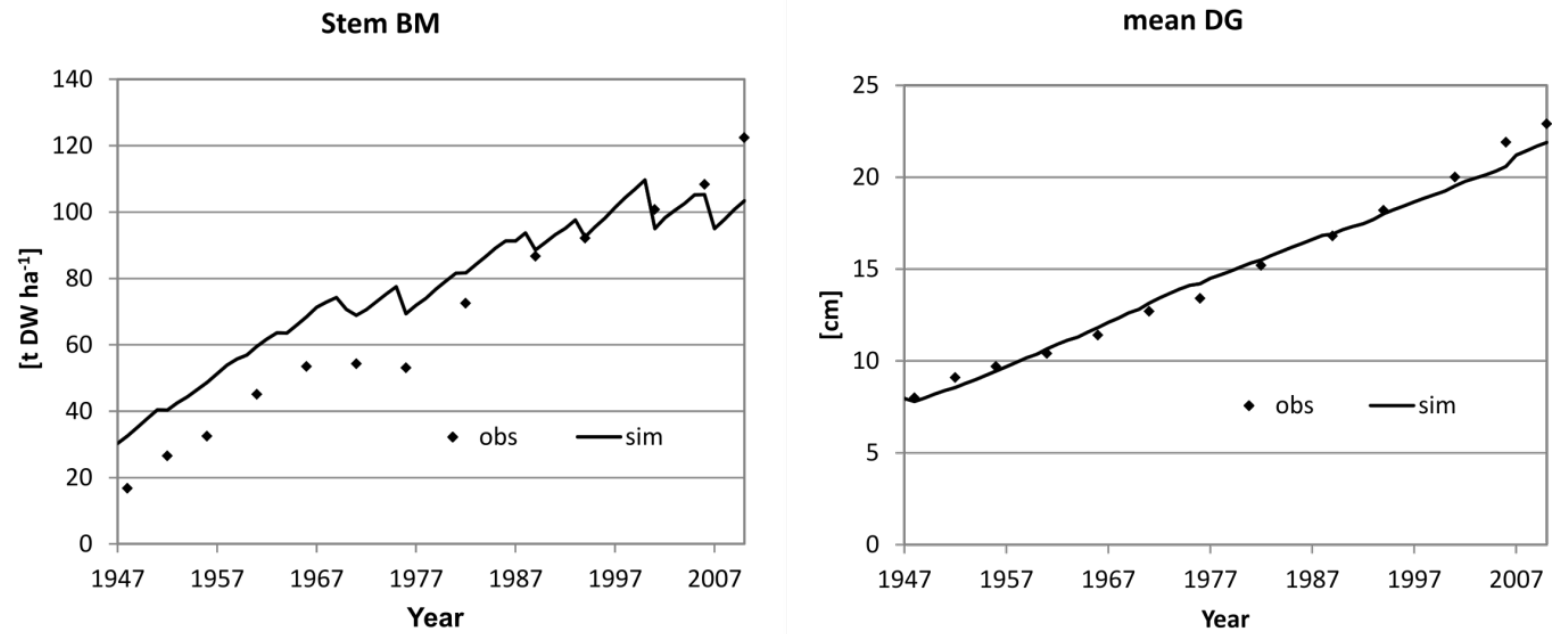

Figure S1 Simulated sim and observed obs DG and stem biomass BM for Peitz. The plots show the time series.
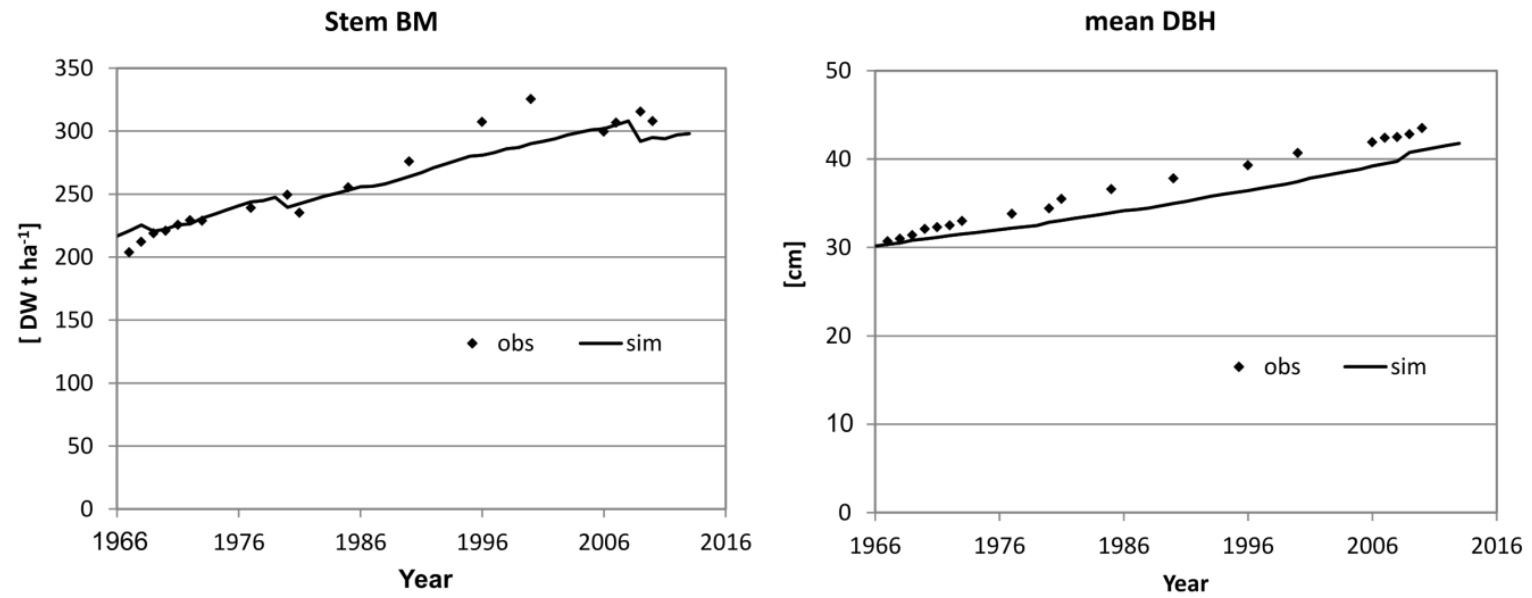

Figure S2 Simulated sim and observed obs DBH and stem biomass BM for Solling. The plots show the time series. 
Stem BM

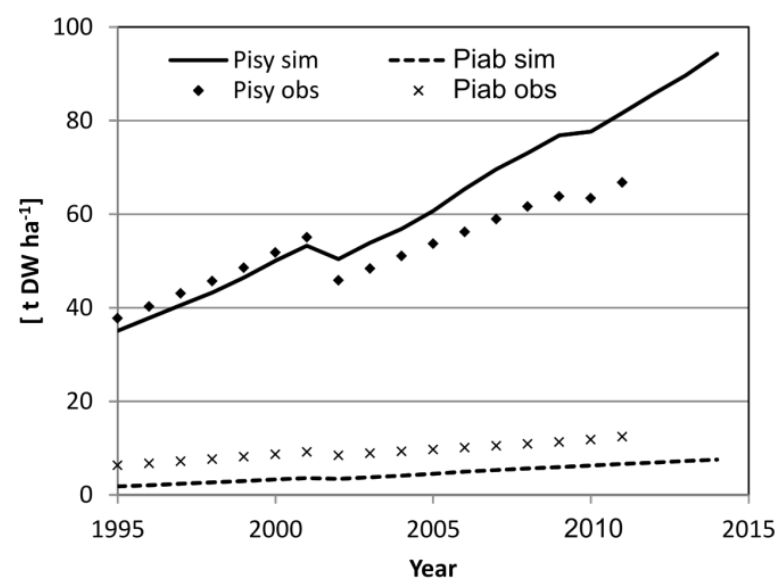

mean DBH

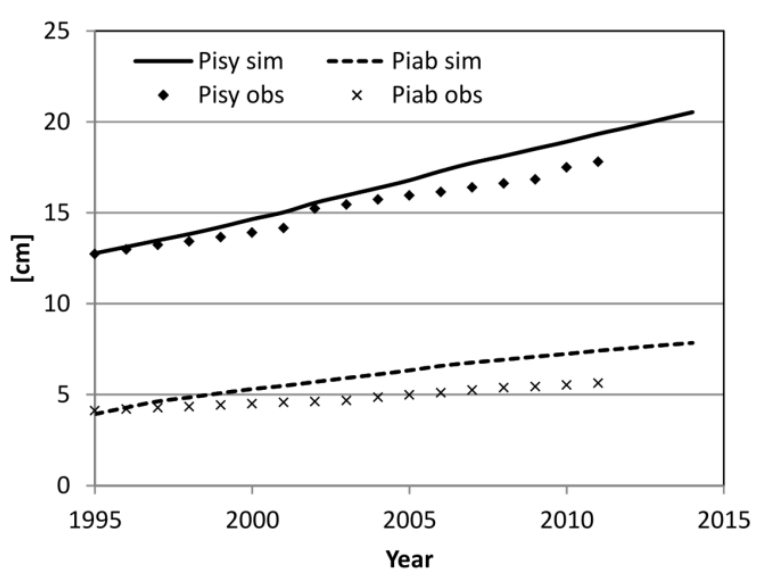

Figure S3 Simulated sim and observed obs DBH and stem biomass BM for Hyytiälä Pisy - pine, Piab - spruce. The plots show the time series. 


\section{S3 FLUXES}

\section{S3.1 Sorø}

\section{S3.1.1 Graphical analysis daily data Sorø}
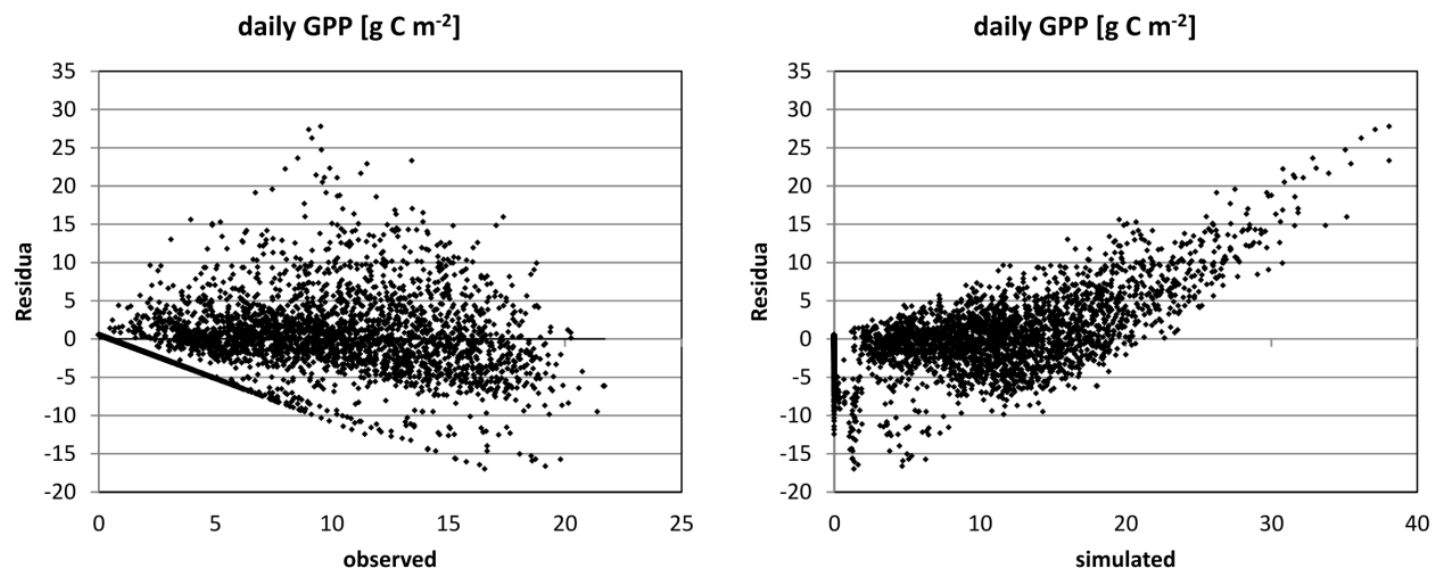

daily NEE $\left[\mathrm{g} \mathrm{C} \mathrm{m}^{-2}\right]$

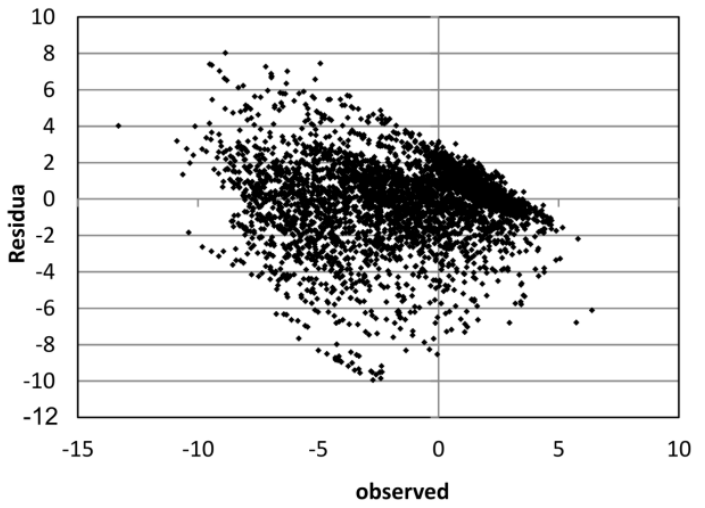

daily NEE $\left[\mathrm{g} \mathrm{C} \mathrm{m}^{-2}\right]$
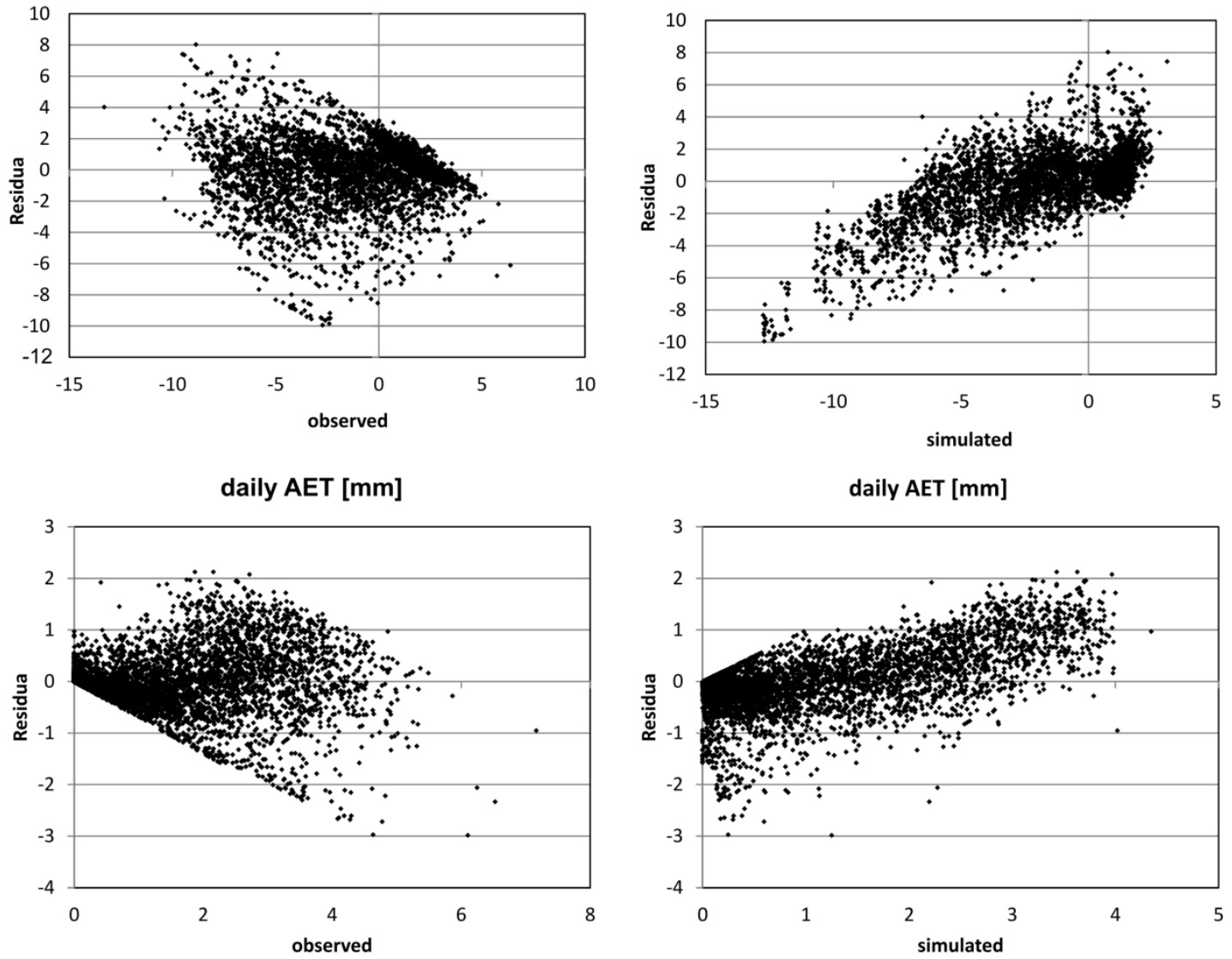

Figure S4 Residual plots of GPP, NEE and AET for Sorø; 1996-2012 
GPP

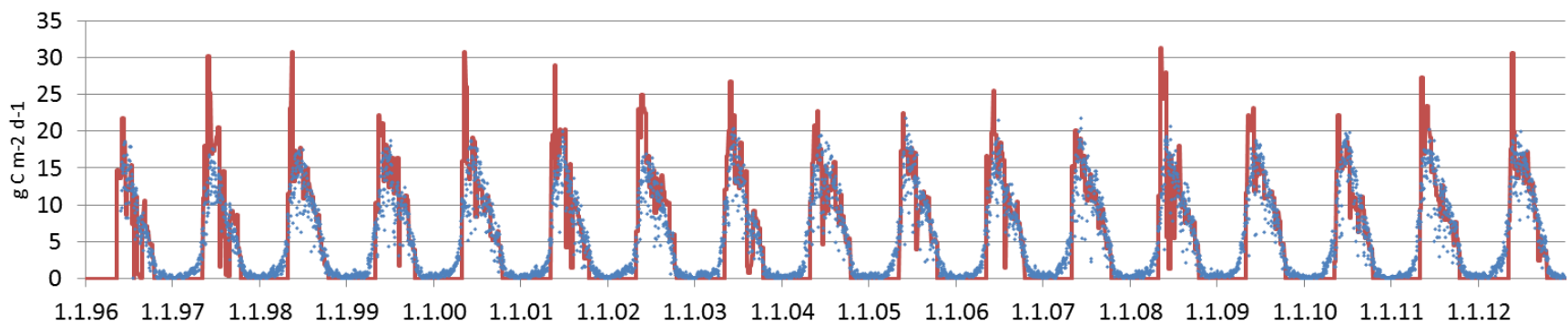

NEE

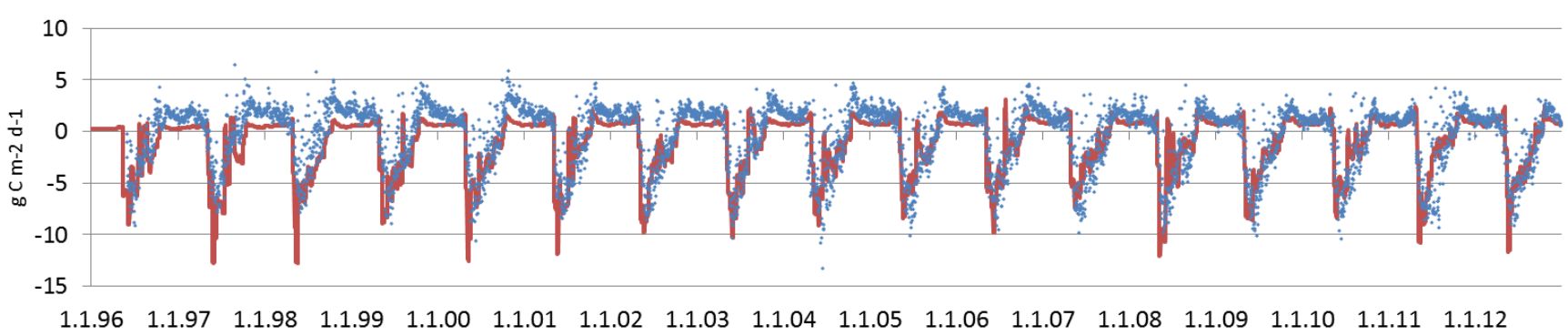

AET

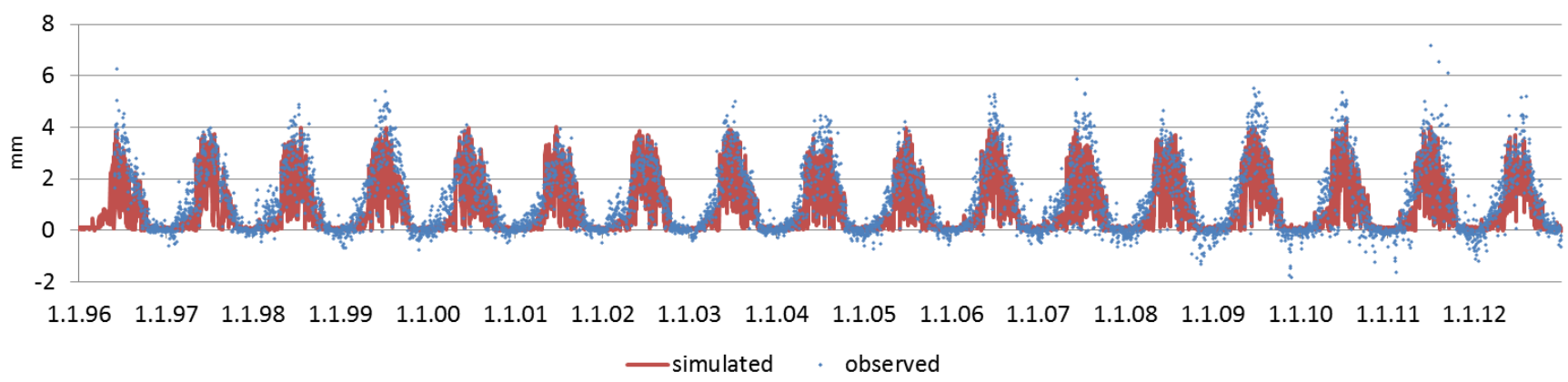

Figure S5 Time series of GPP, NEE, and AET for Sorø; 1996-2012 


\section{S3.1.2 Graphical analysis monthly data Sorø}
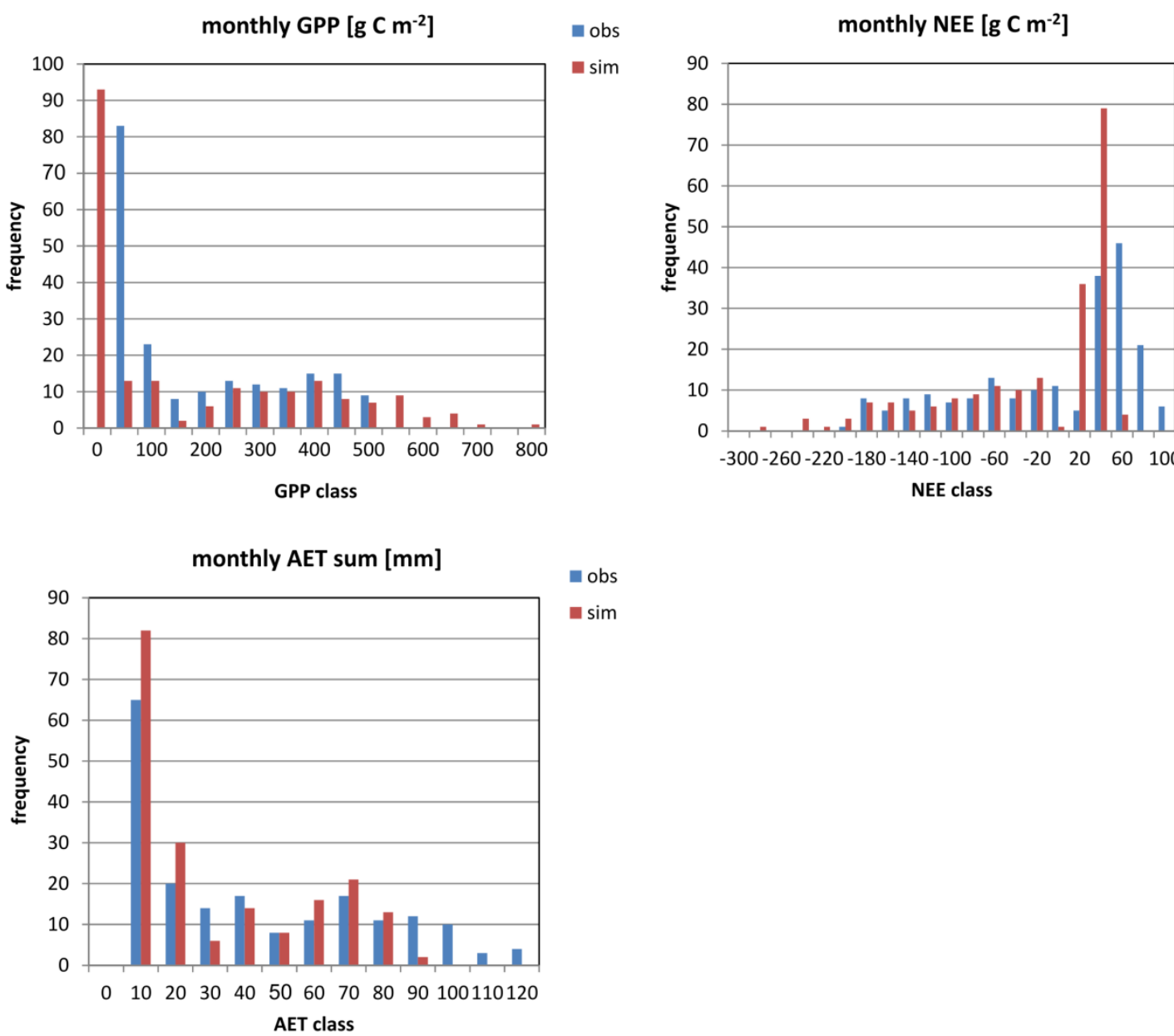

Figure S6 Frequency plots of monthly data of GPP, NEE and AET for Sorø; 1996-2012 

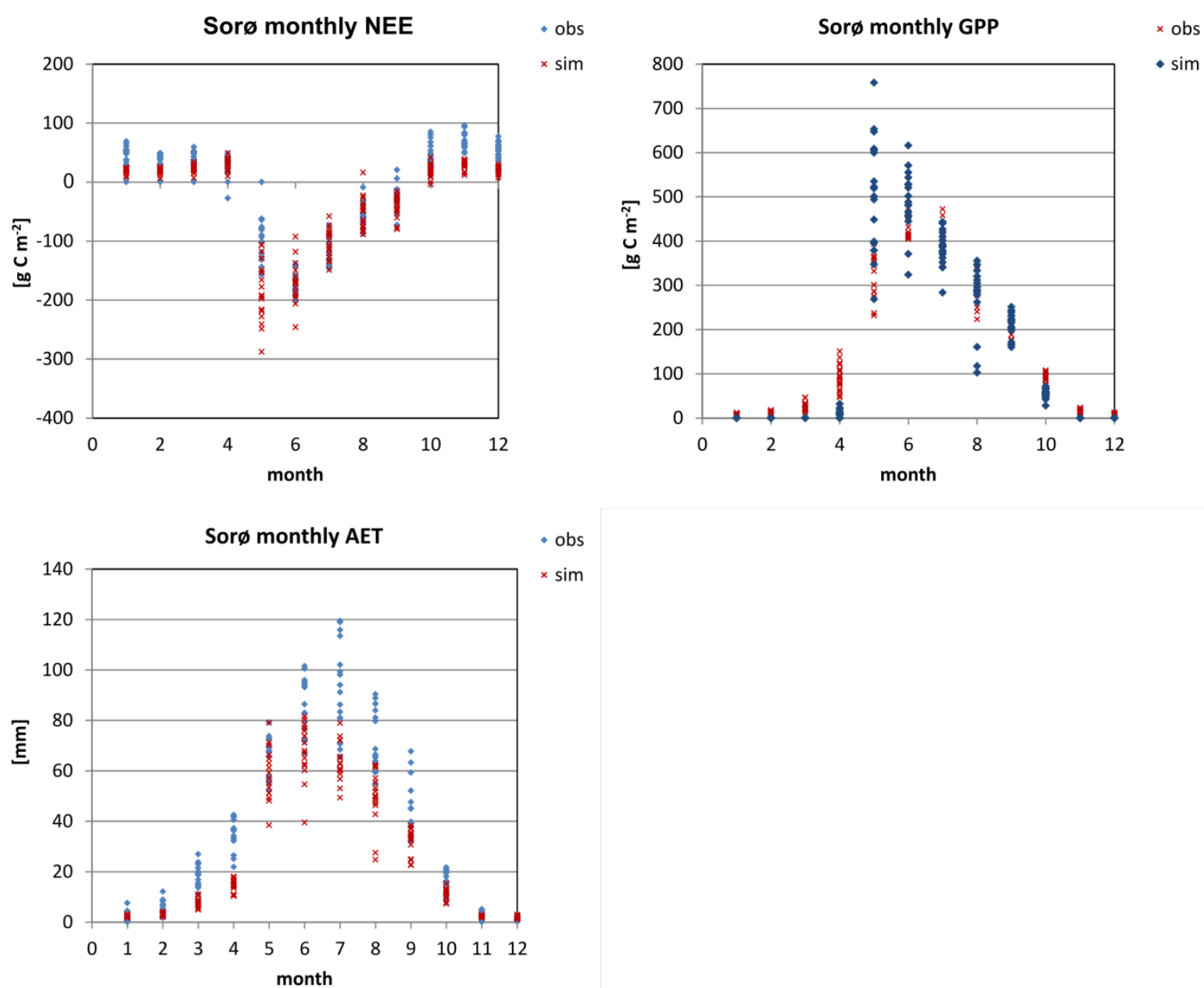

Figure S7 Seasonal cycle of monthly GPP, NEE and AET values obs - observed, sim - simulated for Sorø 


\section{S3.2 Hyytiälä}

\section{S3.2.1 Graphical analysis daily data Hyytiälä}

daily GPP $\left[\mathrm{g} \mathrm{C} \mathrm{m}^{-2}\right]$

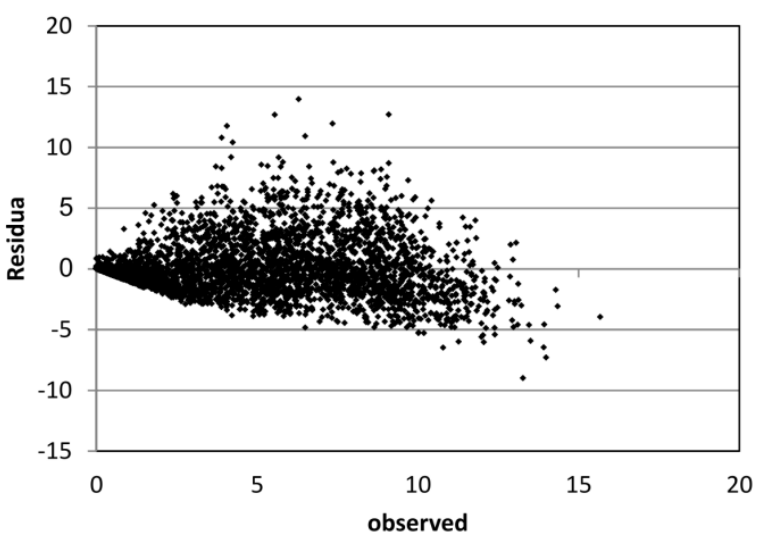

NEE $\left[\mathrm{g} \mathrm{C} \mathrm{m}^{-2}\right]$

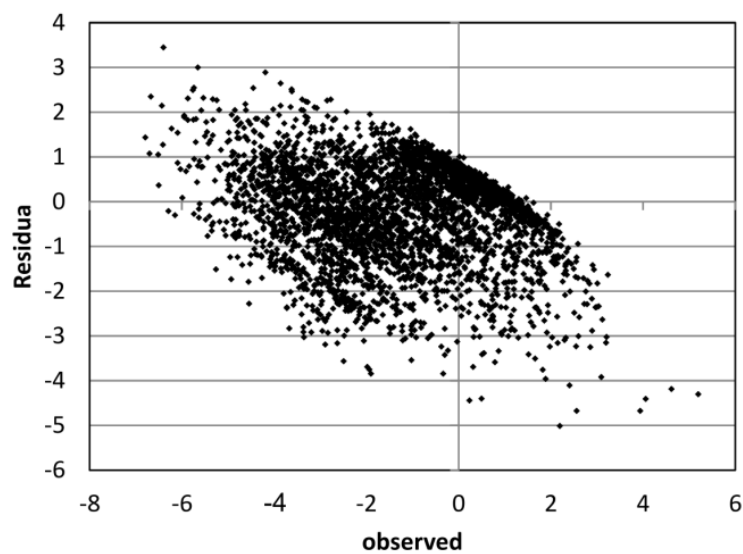

daily AET [mm]

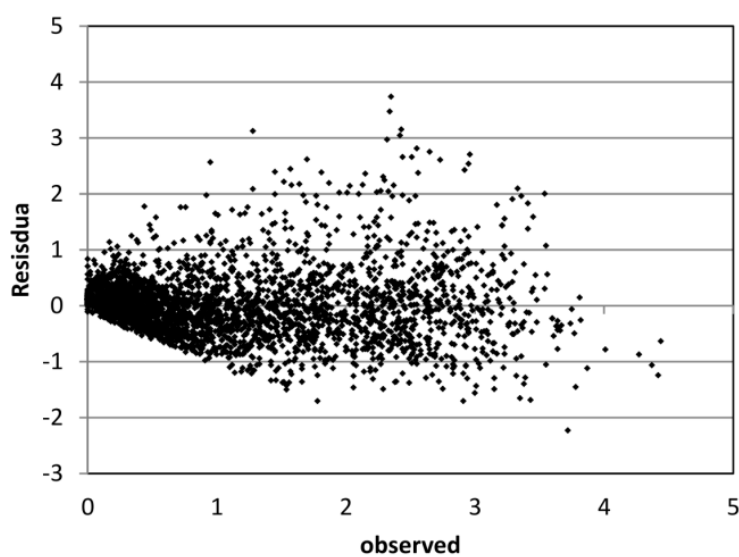

daily GPP $\left[\mathrm{g} \mathrm{C} \mathrm{m}^{-2}\right]$

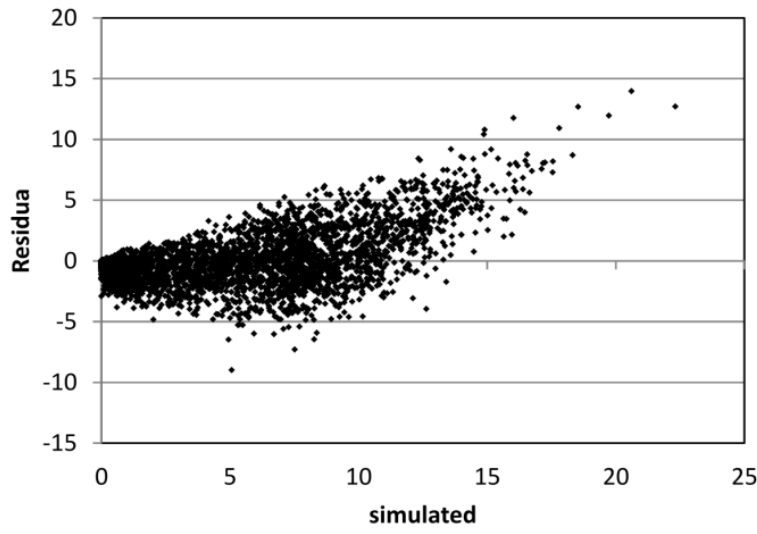

NEE $\left[\mathrm{g} \mathrm{C} \mathrm{m}^{-2}\right]$

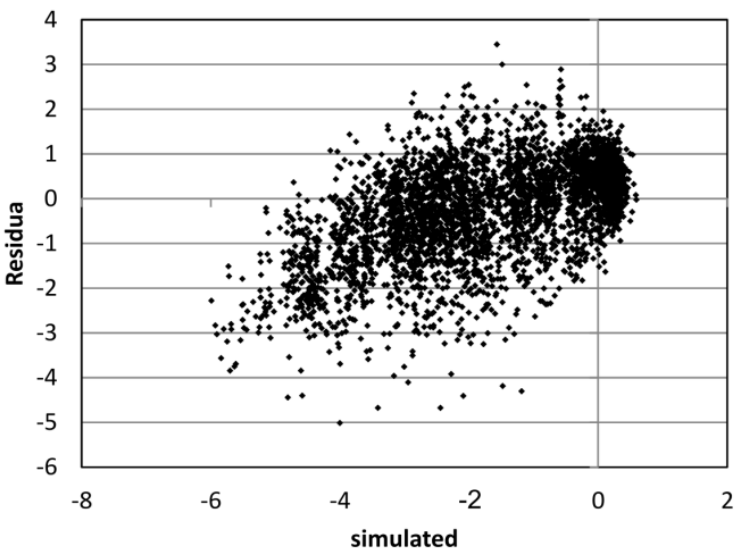

daily AET [mm]

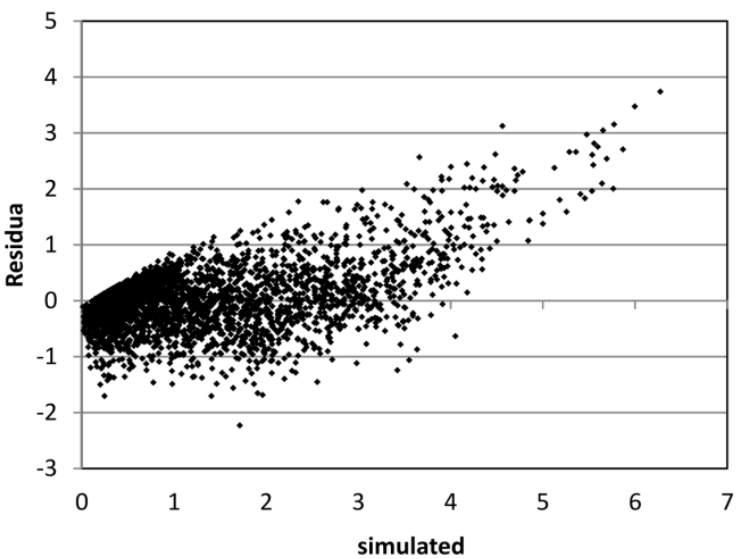

Figure S8 Residual plots of GPP, NEE and AET for Hyytiälä; 1996-2014 

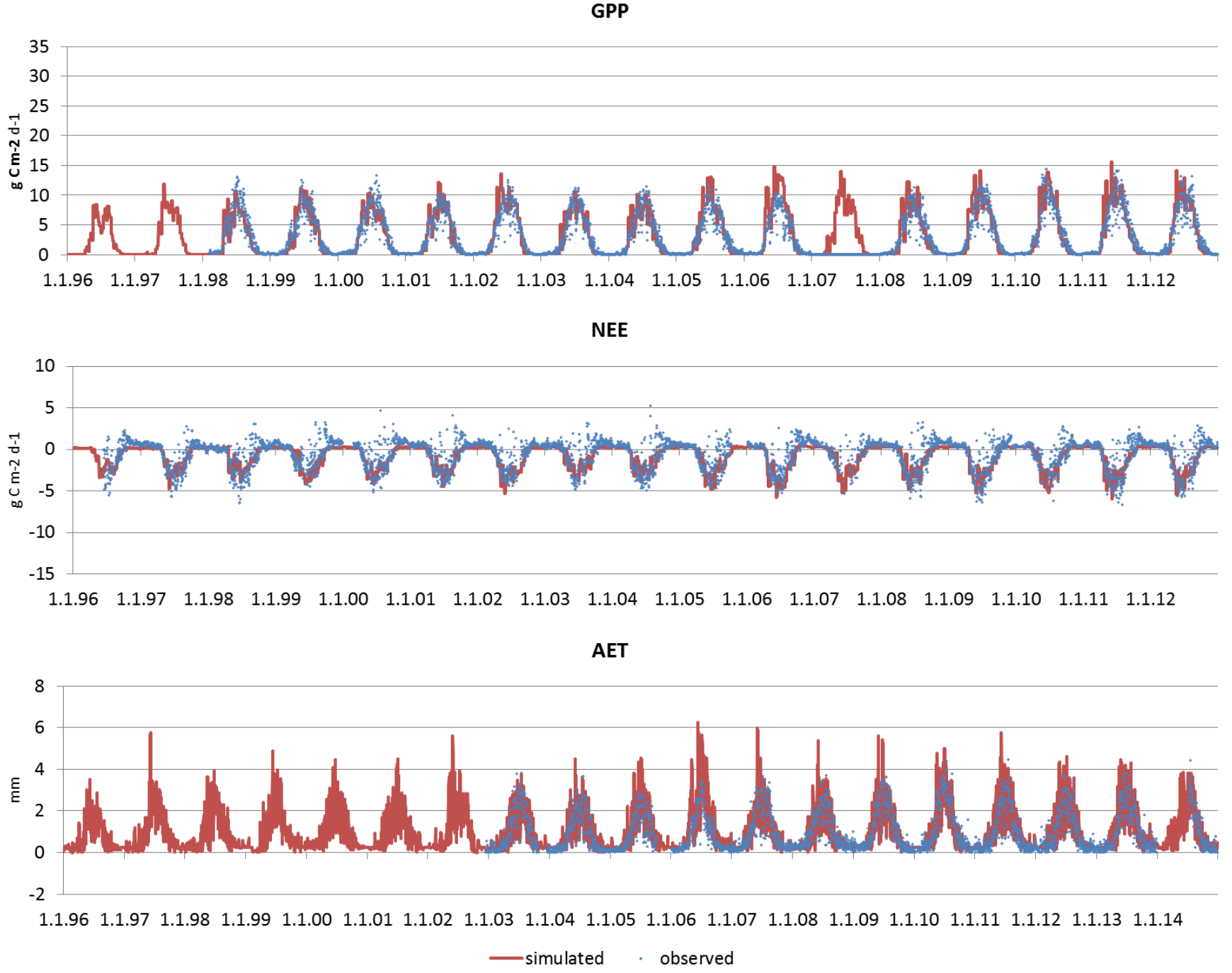

Figure S9 Time series of GPP, NEE, and AET for Hyytiälä; 1996-2014 


\section{S3.2.2 Graphical analysis monthly data Hyytiälä}
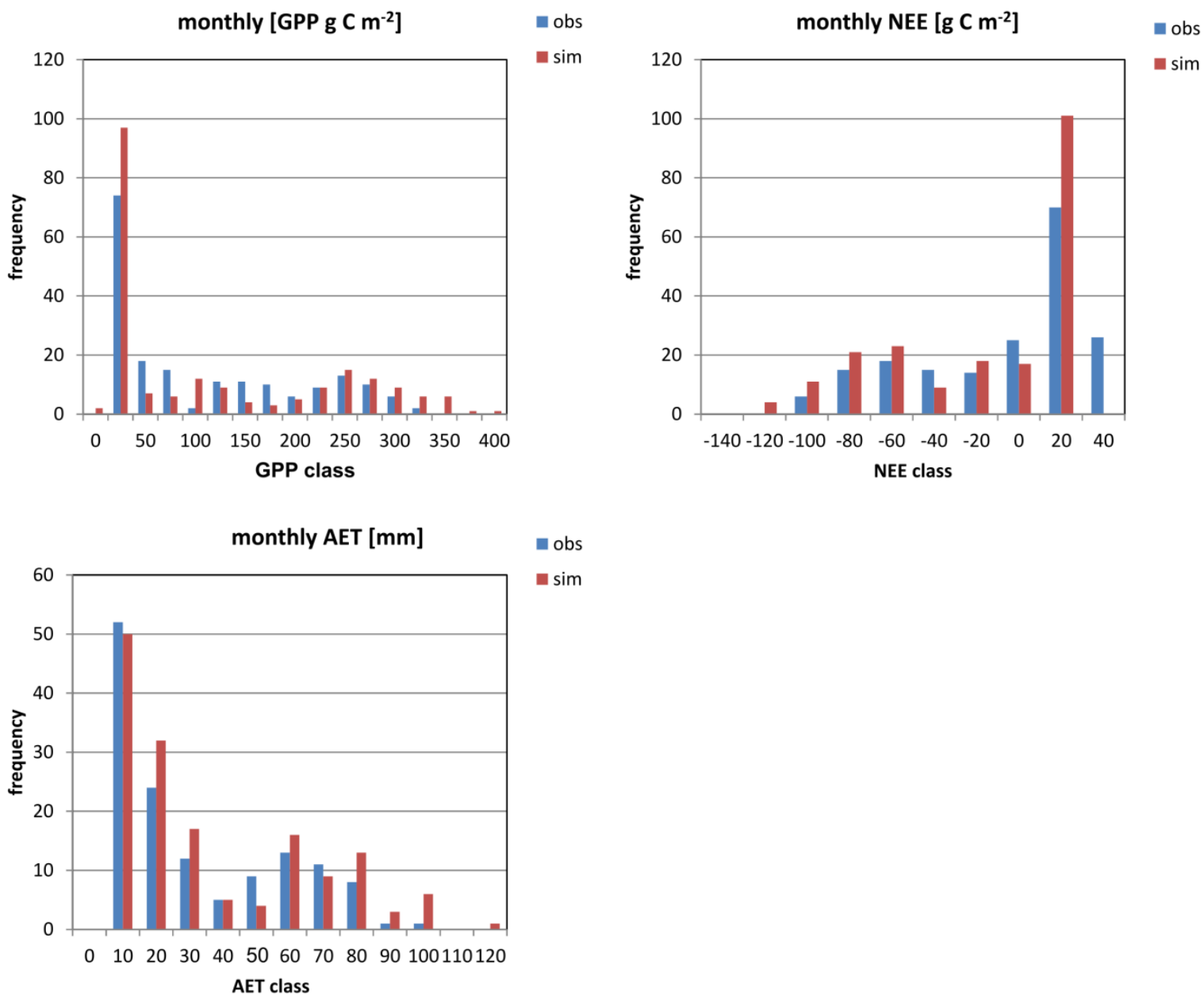

abs

- $\operatorname{sim}$

Figure S10 Frequency plots of monthly GPP, NEE, and AET for Hyytiälä; 1996-2014 

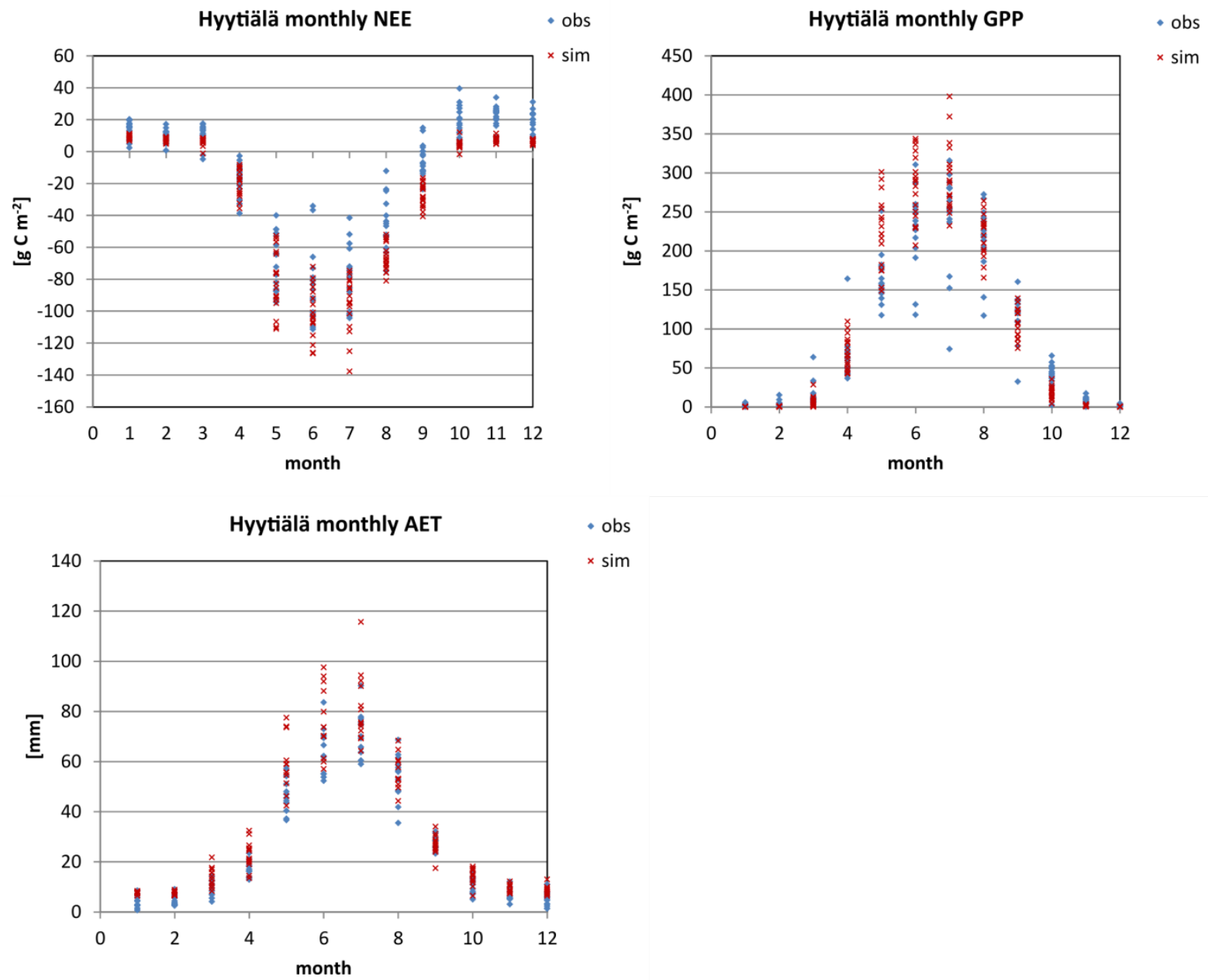

Figure S11 Seasonal cycle of monthly GPP, NEE and AET values obs - observed, sim - simulated in Hyytiälä 
S3.2.3 Graphical analysis of soil temperature and water content Hyytiälä

Hyytiälä Soil temperature

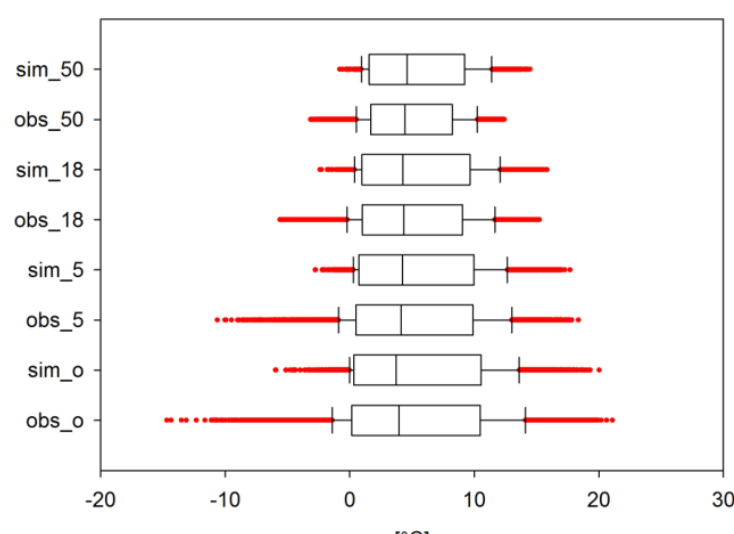

Hyytiälä Soil water content

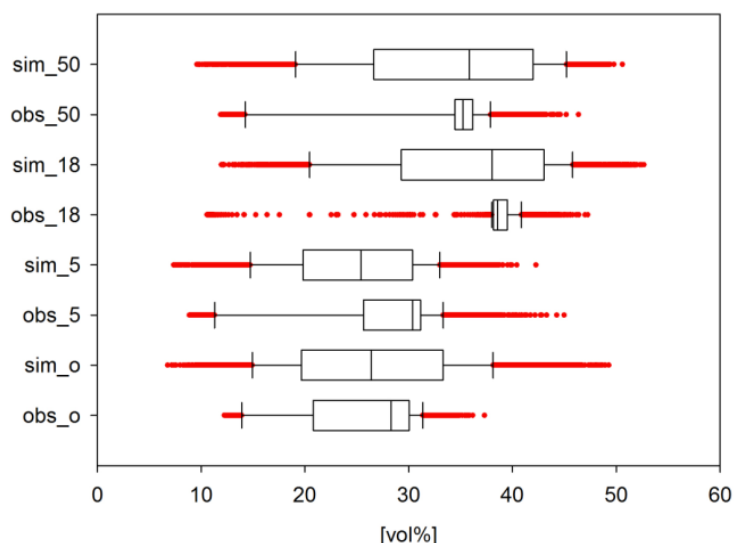

Figure S4. Distribution of magnitude of daily soil temperature and soil water content observed and simulated in different soil layers organic layer, layer in 5, 18, and 50 depth in Hyytiälä. The graph shows the median, the $25^{\text {th }}$ and $75^{\text {th }}$ percentiles box, the $10^{\text {th }}$ and $90^{\text {th }}$ percentiles whiskers and the outliers (red dots). 


\section{S3.3 Analysis of deviations of actual evapotranspiration}

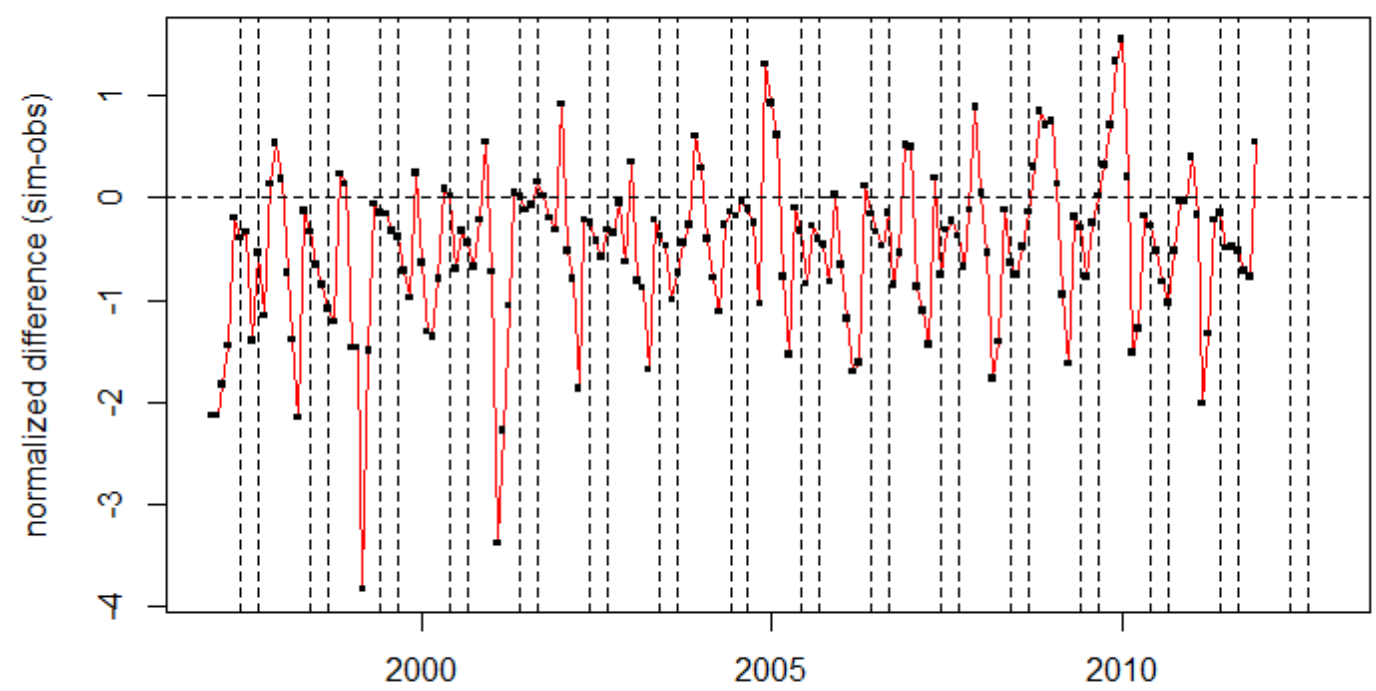

Figure S13. Normalized difference between simulated and observed monthly AET values for the Sorø site. Normalization was done by dividing the mean monthly difference by the mean monthly simulated value. The vertical dashed lines frame the period between June and September.

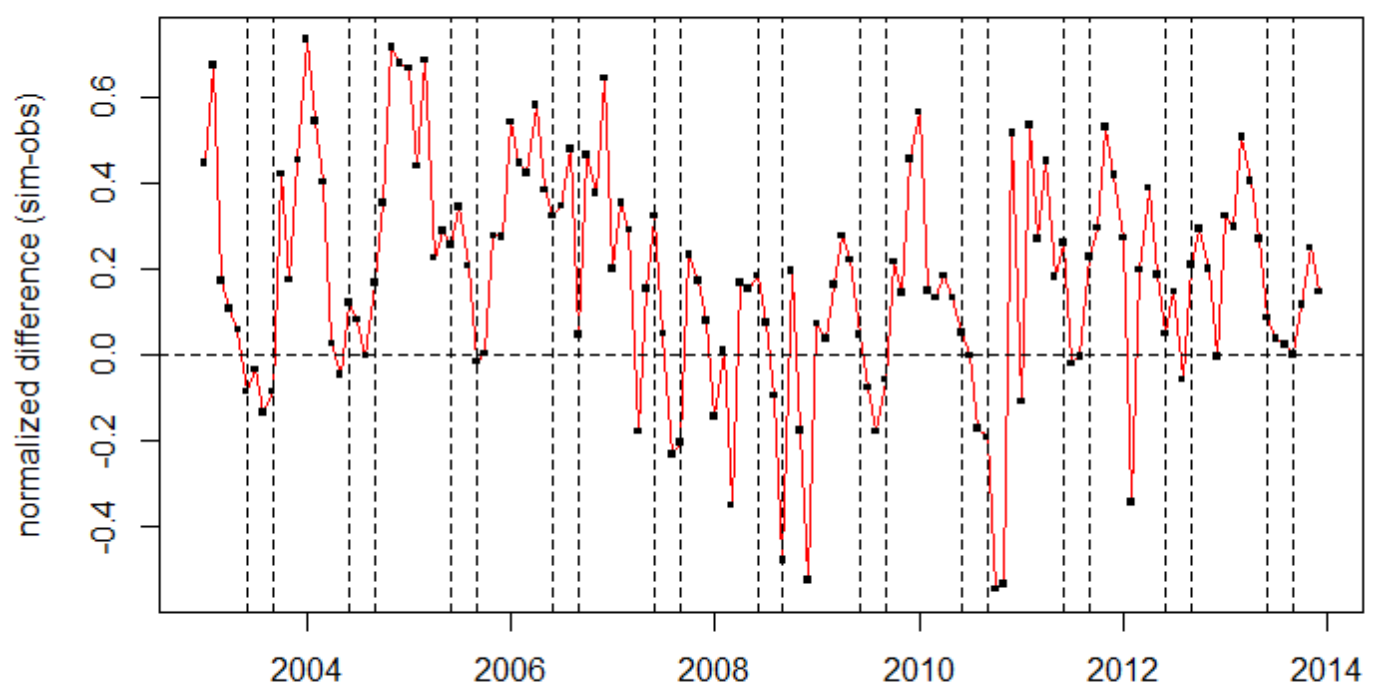

Figure S14. Normalized difference between simulated and observed monthly AET values for the Hyytiälä site. Normalization was done by dividing the mean monthly difference by the mean monthly simulated value. The vertical dashed lines frame the period between June and September. 


\section{S4 SOIL TEMPERATURE AND WATER CONTENT HYYTIÄLÄ}

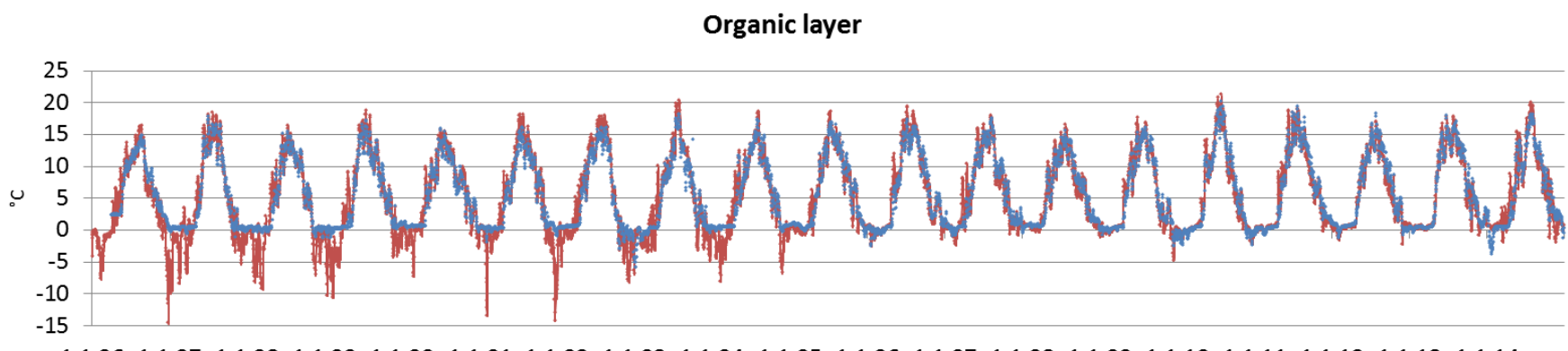

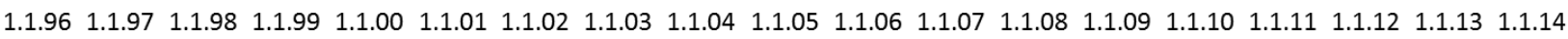

$5 \mathrm{~cm}$

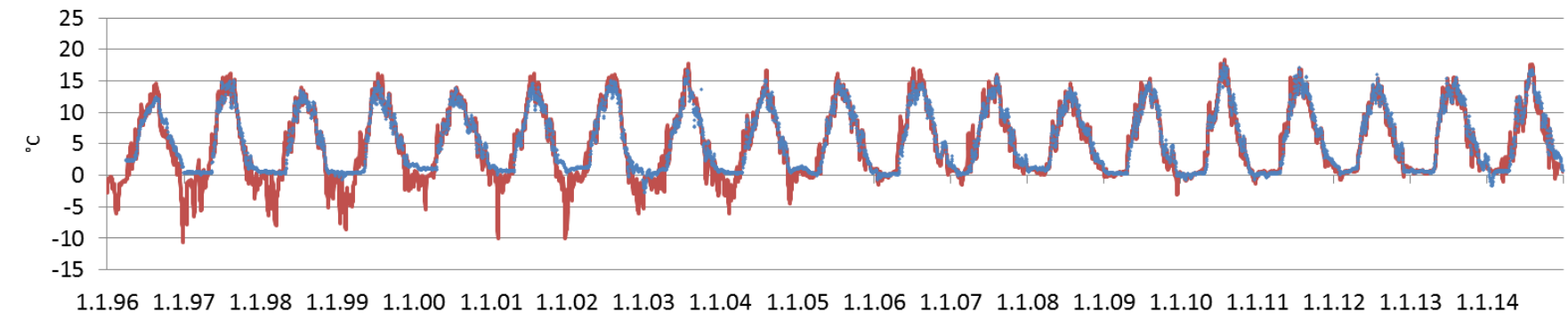

$18 \mathrm{~cm}$

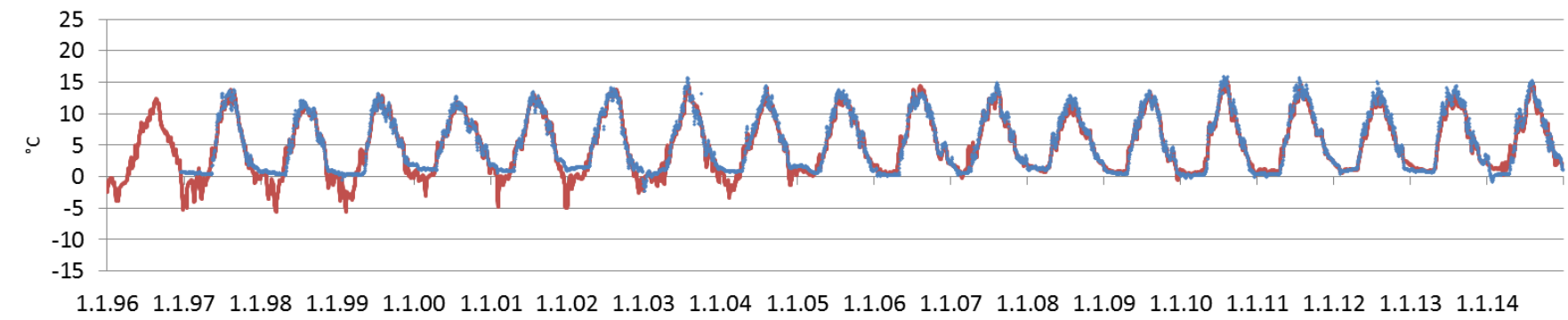

$50 \mathrm{~cm}$

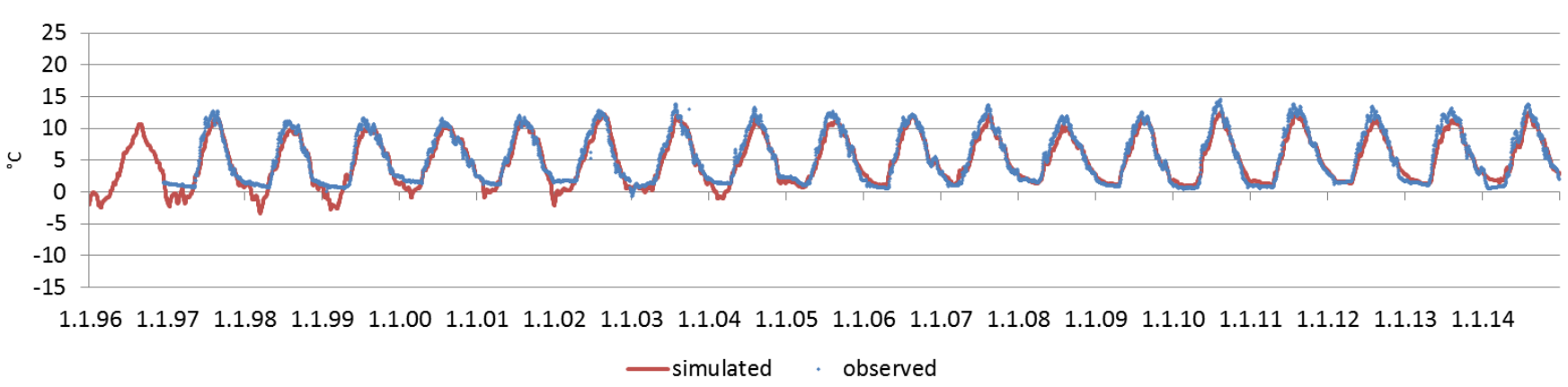

Figure S15. Time series of observed and simulated daily soil temperature for the organic layer and at 5, 18, and $50 \mathrm{~cm}$ depth in Hyytiälä for the period 1996-2014. 


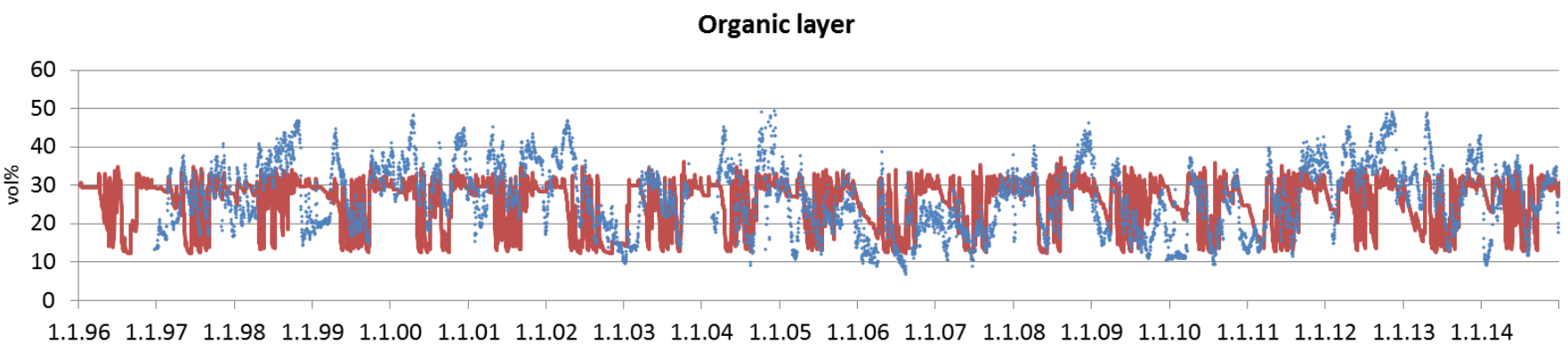

$5 \mathrm{~cm}$
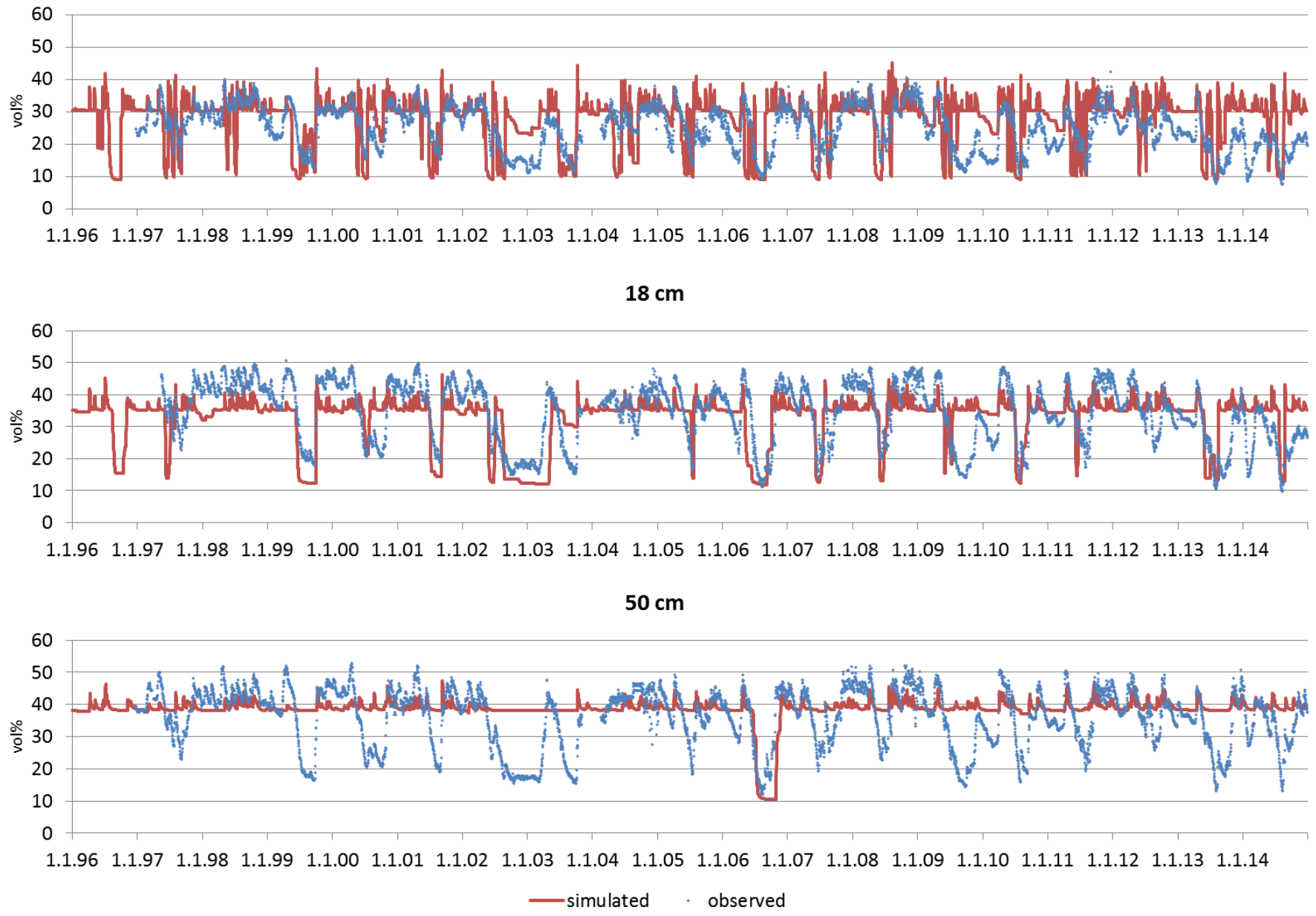

Figure S16. Time series of observed and simulated daily soil water content for the organic layer and at 5, 18, and $50 \mathrm{~cm}$ depth in Hyytiälä for the period 19962014. 


\section{S5 ADDITIONAL DATA}

Table S2 Characteristics of the soil profiles of Peitz, Solling, Hyytiälä, and Sorø

\begin{tabular}{|c|c|c|c|c|c|c|c|c|c|c|c|c|c|}
\hline & \multicolumn{2}{|c|}{ Soil layers } & \multirow[b]{2}{*}{ Clay } & \multirow[b]{2}{*}{$\begin{array}{l}\text { Silt } \\
\text { [mass\% }\end{array}$} & \multirow[b]{2}{*}{ Sand } & \multirow[b]{2}{*}{$\begin{array}{r}\text { Stone } \\
\text { content }\end{array}$} & \multirow[b]{2}{*}{$\begin{array}{r}\text { Pore } \\
\text { volume }\end{array}$} & \multirow[b]{2}{*}{$\begin{array}{l}\text { Field } \\
\text { capacity } \\
{[\text { vol\%] }}\end{array}$} & \multirow[b]{2}{*}{$\begin{array}{r}\text { Wilting } \\
\text { point }\end{array}$} & \multirow[b]{2}{*}{$\begin{array}{r}\text { Bulk density } \\
{\left[\mathrm{g} \mathrm{cm}^{-3}\right]}\end{array}$} & \multirow[b]{2}{*}{ pH } & \multirow[b]{2}{*}{$\mathrm{C} / \mathrm{N}$} & \multirow[b]{2}{*}{$\begin{array}{r}\text { C-content } \\
\text { [mass } \%]\end{array}$} \\
\hline & $\begin{array}{l}\text { Upper } \\
\text { depth } \\
\qquad[\mathrm{cm}]\end{array}$ & $\begin{array}{l}\text { Lower } \\
\text { depth }\end{array}$ & & & & & & & & & & & \\
\hline \multirow[t]{9}{*}{ Peitz } & 6.0 & 0.0 & 0.00 & 0.00 & 0.00 & 0.00 & 81.52 & 30.00 & 12.00 & 0.26 & 2.89 & 22.60 & 42.25 \\
\hline & 0.0 & 5.0 & 7.00 & 6.00 & 87.00 & 0.00 & 44.00 & 26.00 & 7.50 & 1.12 & 2.88 & 33.57 & 2.60 \\
\hline & 5.0 & 10.0 & 7.00 & 6.00 & 87.00 & 0.00 & 44.00 & 26.00 & 7.50 & 1.39 & 3.33 & 46.39 & 0.90 \\
\hline & 10.0 & 20.0 & 7.00 & 2.00 & 91.00 & 0.00 & 44.00 & 26.00 & 7.50 & 1.30 & 3.72 & 41.95 & 0.78 \\
\hline & 20.0 & 30.0 & 7.00 & 2.00 & 91.00 & 0.00 & 44.00 & 26.00 & 7.50 & 1.40 & 4.10 & 44.45 & 0.45 \\
\hline & 30.0 & 40.0 & 7.00 & 2.00 & 91.00 & 0.00 & 44.00 & 26.00 & 7.50 & 1.37 & 4.16 & 58.47 & 0.18 \\
\hline & 40.0 & 60.0 & 7.00 & 2.00 & 91.00 & 0.00 & 44.00 & 26.00 & 7.50 & 1.60 & 4.20 & 23.33 & 0.07 \\
\hline & 60.0 & 130.0 & 0.70 & 1.30 & 98.00 & 0.00 & 52.00 & 25.00 & 9.00 & 1.60 & 4.20 & 25.00 & 0.05 \\
\hline & 130.0 & 200.0 & 3.00 & 1.00 & 96.00 & 0.00 & 52.00 & 25.00 & 9.00 & 1.60 & 4.20 & 0.00 & 0.00 \\
\hline \multirow[t]{6}{*}{ Solling } & 5.8 & 0.0 & 0.00 & 0.00 & 0.00 & 0.00 & 89.80 & 34.00 & 7.00 & 0.14 & 2.88 & 25.52 & 49.69 \\
\hline & 0.0 & 5.0 & 19.67 & 71.07 & 9.27 & 0.83 & 60.99 & 47.94 & 13.74 & 0.82 & 2.83 & 18.57 & 5.29 \\
\hline & 5.0 & 10.0 & 19.67 & 71.07 & 9.27 & 5.00 & 60.99 & 47.94 & 13.74 & 1.02 & 3.21 & 17.39 & 2.94 \\
\hline & 10.0 & 20.0 & 19.67 & 71.07 & 9.27 & 4.67 & 60.99 & 47.94 & 13.74 & 1.05 & 3.69 & 16.18 & 2.06 \\
\hline & 20.0 & 40.0 & 19.50 & 71.20 & 9.30 & 3.83 & 59.20 & 48.93 & 13.72 & 1.11 & 4.11 & 13.01 & 1.22 \\
\hline & 40.0 & 80.0 & 23.80 & 61.13 & 15.07 & 20.00 & 40.61 & 35.58 & 18.88 & 1.37 & 3.99 & 6.69 & 0.31 \\
\hline
\end{tabular}




\begin{tabular}{|c|c|c|c|c|c|c|c|c|c|c|c|c|c|}
\hline & \multicolumn{2}{|c|}{ Soil layers } & \multirow[b]{2}{*}{ Clay } & \multirow{2}{*}{\multicolumn{2}{|c|}{$\begin{array}{l}\text { Silt Sand } \\
\text { [mass\%] }\end{array}$}} & \multirow[b]{2}{*}{$\begin{array}{r}\text { Stone } \\
\text { content }\end{array}$} & \multirow[b]{2}{*}{$\begin{array}{r}\text { Pore } \\
\text { volume }\end{array}$} & \multirow[b]{2}{*}{$\begin{array}{l}\text { Field } \\
\text { capacity } \\
{[\text { vol\%] }}\end{array}$} & \multirow[b]{2}{*}{$\begin{array}{r}\text { Wilting } \\
\text { point }\end{array}$} & \multirow[b]{2}{*}{$\begin{array}{r}\text { Bulk density } \\
{\left[\mathrm{g} \mathrm{cm}^{-3}\right]}\end{array}$} & \multirow[b]{2}{*}{ pH } & \multirow[b]{2}{*}{$C / N$} & \multirow[b]{2}{*}{$\begin{array}{r}\text { C-content } \\
\text { [mass\%] }\end{array}$} \\
\hline & $\begin{array}{l}\text { Upper } \\
\text { depth } \\
{[\mathrm{cn}}\end{array}$ & $\begin{array}{l}\text { Lower } \\
\text { depth }\end{array}$ & & & & & & & & & & & \\
\hline & 80.0 & 100.0 & 31.80 & 46.60 & 21.60 & 23.00 & 37.32 & 36.40 & 24.48 & 1.56 & 3.84 & 2.73 & 0.10 \\
\hline & 100.0 & 150.0 & 31.80 & 46.60 & 21.60 & 96.00 & 35.50 & 30.60 & 26.50 & 2.10 & 4.50 & 0.00 & 0.00 \\
\hline \multirow[t]{6}{*}{ Hyytiälä } & 6.0 & 0.0 & 0.00 & 0.00 & 0.00 & 0.00 & 85.71 & 70.00 & 12.00 & 0.20 & 3.25 & 28.60 & 36.95 \\
\hline & 0.0 & 5.5 & 6.34 & 14.18 & 79.48 & 26.17 & 48.93 & 30.38 & 8.52 & 0.74 & 3.41 & 33.49 & 3.89 \\
\hline & 5.5 & 22.5 & 5.72 & 12.90 & 81.38 & 28.65 & 50.77 & 28.33 & 11.61 & 0.73 & 4.30 & 26.28 & 2.71 \\
\hline & 22.5 & 56.0 & 6.77 & 15.02 & 78.21 & 29.64 & 37.84 & 29.07 & 10.06 & 1.27 & 4.35 & 46.50 & 0.37 \\
\hline & 56.0 & 89.0 & 7.88 & 10.89 & 81.23 & 43.50 & 28.26 & 22.21 & 12.09 & 1.45 & 4.54 & 27.60 & 0.14 \\
\hline & 89.0 & 10.0 & 7.88 & 10.89 & 81.23 & 43.50 & 28.00 & 22.00 & 10.00 & 1.50 & 4.60 & 0.00 & 0.00 \\
\hline \multirow[t]{7}{*}{ Sor $\varnothing$} & 6.0 & 0.0 & 0.00 & 0.00 & 0.00 & 0.00 & 92.86 & 26.40 & 13.10 & 0.10 & 4.66 & 15.86 & 12.70 \\
\hline & 0.0 & 11.0 & 10.10 & 31.00 & 58.90 & 0.00 & 42.00 & 18.90 & 8.70 & 1.29 & 3.33 & 14.62 & 3.23 \\
\hline & 11.0 & 33.0 & 12.70 & 27.40 & 59.90 & 0.00 & 42.00 & 15.40 & 6.40 & 1.61 & 3.92 & 14.51 & 0.74 \\
\hline & 33.0 & 50.0 & 24.40 & 18.30 & 57.30 & 0.00 & 43.00 & 24.20 & 14.80 & 1.45 & 5.13 & 9.44 & 0.68 \\
\hline & 50.0 & 77.0 & 13.90 & 15.10 & 71.00 & 0.00 & 42.00 & 19.00 & 9.10 & 1.46 & 7.04 & 25.37 & 1.04 \\
\hline & 77.0 & 100.0 & 13.90 & 15.10 & 71.00 & 0.00 & 42.00 & 19.00 & 9.10 & 1.88 & 1.32 & 25.00 & 1.21 \\
\hline & 100.0 & 150.0 & 13.90 & 15.10 & 71.00 & 0.00 & 42.00 & 19.00 & 9.10 & 1.88 & 1.32 & 0.00 & 0.00 \\
\hline
\end{tabular}


Table S3 Available time series of observed data, partially with gaps

\begin{tabular}{|c|c|c|c|c|}
\hline Observed data & Peitz & Solling & Hyytiälä & Sorø \\
\hline \multicolumn{5}{|l|}{ Annual data } \\
\hline $\begin{array}{l}\text { Medium height of } \\
\text { dominant trees } \mathrm{HO}\end{array}$ & $1966-2010$ & - & - & - \\
\hline $\begin{array}{l}\text { Mean height of all } \\
\text { trees } \mathrm{MH}\end{array}$ & - & 1967-2010 & 1995-2011 & \\
\hline $\begin{array}{l}\text { Diameter at breast } \\
\text { height } \mathrm{DBH}\end{array}$ & & $1967-2010$ & $1995-2011$ & - \\
\hline $\begin{array}{l}\text { Geometric mean } \\
\text { diameter DG }\end{array}$ & $1966-2010$ & - & - & - \\
\hline $\begin{array}{l}\text { Stem biomass } \\
\text { STBIOM }\end{array}$ & - & $1967-2010$ & $1995-2011$ & - \\
\hline Stem volume STVOL & $1966-2010$ & - & - & - \\
\hline Number of trees & $1966-2010$ & $1967-2010$ & $1995-2011$ & - \\
\hline $\begin{array}{l}\text { Net ecosystem } \\
\text { production NEP }\end{array}$ & - & - & $1995-2014$ & $1997-2012$ \\
\hline $\begin{array}{l}\text { Gross primary } \\
\text { productivity GPP }\end{array}$ & - & - & $1995-2014$ & $1997-2012$ \\
\hline $\begin{array}{l}\text { Actual } \\
\text { evapotranspiration } \\
\text { AET }\end{array}$ & - & - & $1995-2013$ & $1997-2012$ \\
\hline \multicolumn{5}{|l|}{ Daily data } \\
\hline $\begin{array}{l}\text { Net ecosystem } \\
\text { exchange NEE }\end{array}$ & - & & 1996-2014 & $1996-2012$ \\
\hline $\begin{array}{l}\text { Total ecosystem } \\
\text { respiration TER }\end{array}$ & - & & 1998-2014 & 1996-2012 \\
\hline $\begin{array}{l}\text { Gross primary } \\
\text { productivity GPP }\end{array}$ & - & & 1998-2014 & 1996-2012 \\
\hline $\begin{array}{l}\text { Actual } \\
\text { evapotranspiration } \\
\text { AET }\end{array}$ & - & & 2003-2014 & 1996-2012 \\
\hline $\begin{array}{l}\text { Soil temperature } \\
\text { organic layer }\end{array}$ & - & & 1996-2014 & - \\
\hline $\begin{array}{l}\text { Soil temperature } \\
2 \mathrm{~cm}\end{array}$ & - & & - & $1996-2012$ \\
\hline $\begin{array}{l}\text { Soil temperature } \\
5 \mathrm{~cm} 0-10 \mathrm{~cm}\end{array}$ & - & & 1996-2014 & 1996-2012 \\
\hline $\begin{array}{l}\text { Soil temperature } \\
18 \mathrm{~cm} 10-25 \mathrm{~cm}\end{array}$ & - & & 1997-2014 & - \\
\hline $\begin{array}{l}\text { Soil temperature } \\
50 \mathrm{~cm} 40-60 \mathrm{~cm}\end{array}$ & - & & 1997-2014 & - \\
\hline Water content & - & & 1997-2014 & - \\
\hline
\end{tabular}


Lasch-Born et al., Electronic supplement material (ESM)

\begin{tabular}{|c|c|c|c|c|}
\hline Observed data & Peitz & Solling & Hyytiälä & Sorø \\
\hline \multicolumn{5}{|l|}{ organic layer } \\
\hline $\begin{array}{l}\text { Water content } 5 \mathrm{~cm} \\
0-10 \mathrm{~cm}\end{array}$ & - & & $1997-2014$ & - \\
\hline $\begin{array}{l}\text { Water content } 8 \mathrm{~cm} \\
0-16 \mathrm{~cm}\end{array}$ & - & & - & 1996-2012 \\
\hline $\begin{array}{l}\text { Water content } \\
18 \mathrm{~cm} 10-25 \mathrm{~cm}\end{array}$ & - & & $1997-2014$ & - \\
\hline $\begin{array}{l}\text { Water content } \\
50 \mathrm{~cm} 40-60 \mathrm{~cm}\end{array}$ & - & & $1997-2014$ & - \\
\hline
\end{tabular}




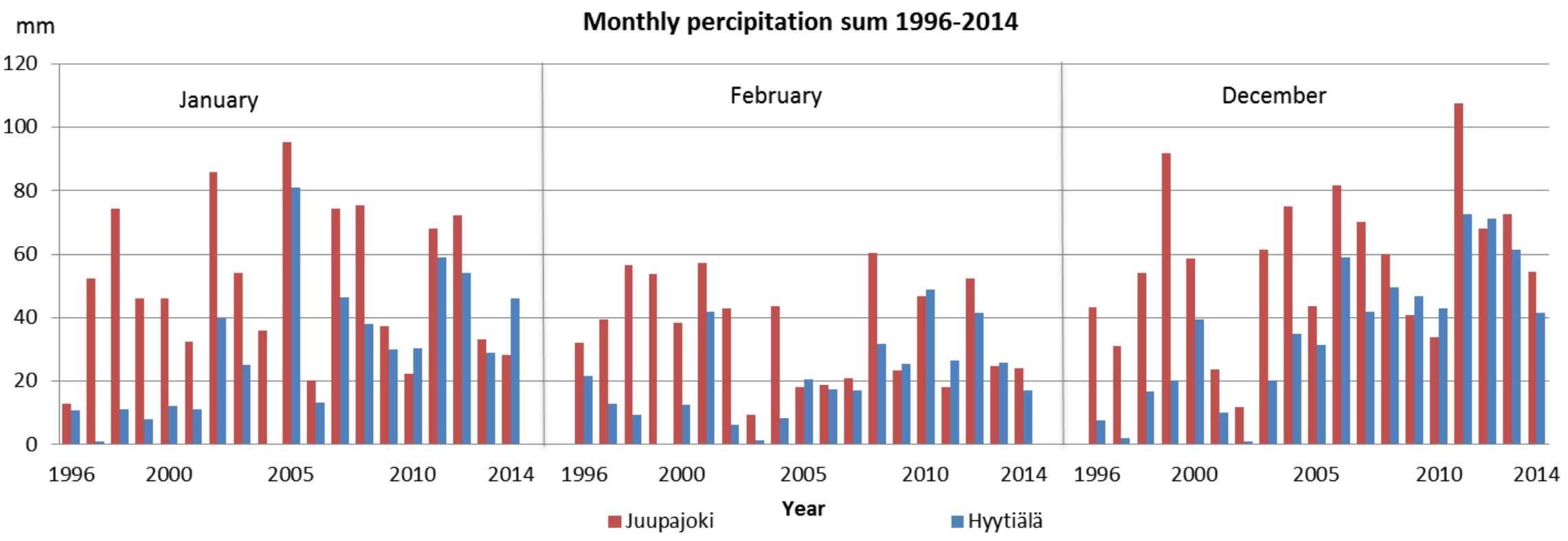

Figure S17 Monthly precipitation sum of the winter month 1996-2014. Comparison of the data from the observation station Hyytiälä and the nearby weather station of the Finnish Meteorological Institute Juupajoki https://en.ilmatieteenlaitos.fi/download-observations\#!/, download 23.02.2018. The distance between the two stations is about $300 \mathrm{~m}$. 


\section{REFERENCES}

Badeck, F.W. et al., 2005. Adaptive Forest Management at the Scale of the Forest Management Units. In: S. Kellomäki and S. Leinonen Editors, Management of European Forests under Changing Climatic Conditions. University of Joensuu, Faculty of Forestry, Joensuu, Fi, pp. 315 - 382.

Borys, A. et al., 2015. Ökonomische Analyse der Kohlenstoffsequestrierung in Buchenbeständen im Kontext von Waldpflege und Klimawandel. Allg. Forst- u. J. Ztg., 1863/4: 72-84.

Borys, A., Lasch, P., Suckow, F. and Reyer, C., 2013. Kohlenstoffspeicherung in Buchenbeständen in Abhängigkeit von Waldpflege und Klimawandel. Allg. Forst- u. J.Ztg., 1841/2: 26-35.

Borys, A., Suckow, F., Reyer, C., Gutsch, M. and Lasch-Born, P., 2016. The impact of climate change under different thinning regimes on carbon sequestration in a German forest district. Mitig Adapt Strateg Glob Change, 216: 861-881.

Bugmann, H. et al., 2019. Tree mortality submodels drive simulated long-term forest dynamics: assessing 15 models from the stand to global scale. Ecosphere, 102: e02616.

Fürstenau, C. et al., 2007. Multiple-use forest management in consideration of climate change and the interests of stakeholder groups. European Journal of Forest Research, 1262: 225-239.

Gerstengarbe, F.-W. et al., 2003. Studie zur klimatischen Entwicklung im Land Brandenburg bis 2055 und deren Auswirkungen auf den Wasserhaushalt, die Forst- und Landwirtschaft sowie die Ableitung erster Perspektiven. 83, PIK, Potsdam.

Gutsch, M., Lasch-Born, P., Kollas, C., Suckow, F. and Reyer, C.O.P., 2018. Balancing tradeoffs between ecosystem services in Germany's forests under climate change. Environmental Research Letters, 134: 045012.

Gutsch, M. et al., 2015a. Uncertainty of biomass contributions from agriculture and forestry to renewable energy resources under climate change. Meteorologische Zeitschrift, 242: 1-11.

Gutsch, M., Lasch-Born, P., Suckow, F. and Reyer, C., 2015b. Modeling of Two Different Water Uptake Approaches for Mono- and Mixed-Species Forest Stands. Forests, 66: 2125-2147.

Gutsch, M., Lasch-Born, P., Suckow, F. and Reyer, C.P.O., 2016. Evaluating the productivity of four main tree species in Germany under climate change with static reduced models. Annals of Forest Science, 732: 401-410.

Gutsch, M., Lasch, P., Suckow, F. and Reyer, C., 2011. Management of mixed oak-pine forests under climate scenario uncertainty. For. Syst., 203: 453-463.

Horemans, J., A. et al., 2017. Combining multiple statistical methods to evaluate the performance of process-based vegetation models across three forest stands. Central European Forestry Journal, 634: 153-172.

Kint, V., Lasch, P., Lindner, M. and Muys, B., 2009. Multipurpose conversion management of Scots pine towards mixed oak-birch stands--A long-term simulation approach. For. Ecol. Manage., 2571: 199-214. 
Kollas, C., Gutsch, M., Hommel, R., Lasch-Born, P. and Suckow, F., 2018. Mistletoe-induced growth reductions at the forest stand scale. Tree Physiol, 385: 1-10.

Kollas, C., Lasch, P., Rock, J. and Suckow, F., 2009. Bioenergy potential in Germany - assessing spatial patterns of biomass production with aspen short-rotation coppice. International Agrophysics, 234: 343-352.

Lasch-Born, P. et al., 2018. Fire, late frost, nun moth and drought risks in Germany's forests under climate change. Meteorologische Zeitschrift, 272: 135.-148.

Lasch-Born, P. et al., 2015. Forests under climate change: potential risks and opportunities. Meteorologische Zeitschrift, 242: 157-172.

Lasch, P., Badeck, F.-W., Lindner, M. and Suckow, F., 2002. Sensitivity of simulated forest growth to changes in climate and atmospheric $\mathrm{CO}_{2}$. Forstwiss. Centralblatt, 121, Supplement 1: 155-171.

Lasch, P., Kollas, C., Rock, J. and Suckow, F., 2010. Potentials and impacts of short-rotation coppice plantation with aspen in Eastern Germany under conditions of climate change. Reg Environ Change, 102: 83-94.

Lasch, P., Schröder, J., Suckow, F., Gutsch, M. and Degenhardt, A., 2009. Nutzung von Modellen zur Vorbereitung auf die Zukunft. In: M. Elmer et al. Editors, Nachhaltige Bewirtschaftung von Eichen-Kiefern-Mischbeständen. Oekom Verlag, München, pp. 119-135.

Lasch, P., Suckow, F. and Badeck, F.-W., 2007. Analyses of forest ecosystems' response to climate change at level II monitoring sites. In: J. Eichhorn Editor, Symposium: Forests in a Changing Environment - Results of 20 years ICP Forests Monitoring Göttingen, 25.-28.10.2006. Schriften aus der Forstlichen Fakultät der Universität Göttingen und der Nordwestdeutschen Forstlichen Versuchsanstalt. J.D. Sauerländer's Verlag Frankfurt am Main, Göttingen, pp. 136-141.

Meiwes, K.-J. et al., 2007. Kohlenstoffumsatz in Waldökosystemen und deren Böden. Parametrisierung, Kalibrierung und Validierung von Modellen. AFZ / Der Wald20/2007: 1076-1078.

Reyer, C. et al., 2014. Projections of regional changes in forest net primary productivity for different tree species in Europe driven by climate change and carbon dioxide. Annals Of Forest Science, 712: 211-225.

Reyer, C., Lasch, P., Mohren, G.M.J. and Sterck, F.J., 2010. Inter-specific competition in mixed forests of Douglas-fir Pseudotsuga menziesii and common beech Fagus sylvatica under climate change - a model-based analysis. Annals Of Forest Science, 678.

Reyer, C.P.O., Flechsig, M., Lasch-Born, P. and van Oijen, M., 2016. Integrating parameter uncertainty of a process-based model in assessments of climate change effects on forest productivity. Clim. Change, 137: 395-409.

Schelhaas, M.-J. et al., 2015. Alternative forest management strategies to account for climate change-induced productivity and species suitability changes in Europe. Reg Environ Change, 158: 1581-1594.

Seidl, R., Rammer, W., Lasch, P., Badeck, F.W. and M.J., L., 2008. Does conversion of evenaged, secondary coniferous forest affect carbon sequestration? A simulation study under changing environmental conditions. Silva Fennica, 423: 369-386. 
Stojanović, D. et al., 2014. Impact of climate change and different managment regimes to various ecosystem services in European beech forests in Serbia. CONTEMPORARY AGRICULTURE / SAVREMENA POLJOPRIVREDA, 63312-325.

Suckow, F., Lasch-Born, P., Gerstengarbe, F.-W., Werner, P. and Reyer, C.P.O., 2016. Climate change impacts on a pine stand in Central Siberia. Reg Environ Change, 166: 16711683.

van Oijen, M. et al., 2013. Bayesian calibration, comparison and averaging of six forest models, using data from Scots pine stands across Europe. For. Ecol. Manage., 289: 255-268.

Wechsung, F., Gerstengarbe, F.W., Lasch, P. and Lüttger, A. Editors, 2009. Die Ertragsfähigkeit ostdeutscher Ackerflächen unter Klimawandel. PIK-Report, 112. PIK, Potsdam, $93 \mathrm{pp}$.

Yousefpour, R. et al., 2018. Realizing Mitigation Efficiency of European Commercial Forests by Climate Smart Forestry. Scientific Reports, 81: 345. 